\title{
Legumes in the reclamation of marginal soils, from cultivar and inoculant selection to transgenic approaches
}

\author{
Teodoro Coba de la Peña • José J. Pueyo
}

Accepted: 13 October 2010 /Published online: 18 March 2011

(C) INRA and Springer Science+Business Media B.V. 2011

\begin{abstract}
Mineral nitrogen deficiency is a frequent characteristic of arid and semi-arid soils. Biological nitrogen fixation by legumes is a sustainable and environmentalfriendly alternative to chemical fertilization. Therefore, legumes have a high potential for the reclamation of marginal soils. Such issue is becoming more urgent due to the ever-rising requirement for food and feed, and the increasing extension of salinized and degraded lands, both as a consequence of global change and irrigation practices. This manuscript reviews current research on physiological and molecular mechanisms involved in the response and tolerance to environmental stresses of the Rhizobiumlegume symbiosis. We report in particular recent advances on the isolation, characterization, and selection of tolerant rhizobial strains and legume varieties, both by traditional methods and through biotechnological approaches. The major points are the following. (1) Understanding mechanisms involved in stress tolerance is advancing fast, thus providing a solid basis for the selection and engineering of rhizobia and legumes with enhanced tolerance to environmental constraints. (2) The considerable efforts to select locally adapted legume varieties and rhizobial inocula that can fix nitrogen under conditions of drought or salinity are generating competitive crop yields in affected soils. (3) Biotechnological approaches are used to obtain improved legumes and rhizobia with enhanced tolerance to abiotic stresses, paying particular attention to the sensitive nitrogen-fixing activity. Those biotechnologies are yielding transgenic crops and inocula with unquestionable potential.
\end{abstract}

T. Coba de la Peña $\cdot$ J. J. Pueyo $(\bowtie)$

Instituto de Ciencias Agrarias, CSIC,

Serrano 115-bis,

28006 Madrid, Spain

e-mail: pueyo@ccma.csic.es

e-mail: pueyo@ica.csic.es
In conclusion, the role of legumes in sustainable agriculture, and particularly, their use in the reclamation of marginal lands, certainly has a very promising future.

Keywords Legume $\cdot$ Rhizobium · Soil · Nitrogen fixation . Nodule $\cdot$ Stress $\cdot$ Salinity $\cdot$ Drought

Contents

1. Introduction. . . . . . . . . . . . . 2

2. The Rhizobium-legume symbiosis under environmental constraints. . . . . . . . . . . . . . . 3

2.1. Effects of abiotic stresses on free-living rhizobia. .3

2.2. Effects of environmental stress on legumes and their symbiotic performance. . . . . . . . . . 4

2.2.1. Plant growth and photosynthesis. . . . . .4

2.2.2. Nodule formation, structure, and physiology. . . . . . . . . . . 5

3. Rhizobial inoculants in the reclamation of marginal soils. . . . . . . . . . . . . . . . . . . 7

3.1. Selection of rhizobial inoculants that nodulate legumes in stressed environments. . . . . . . .8

3.2. Rhizobia as endophytes and plant growth promoting rhizobacteria in legumes and non-legumes. .10

3.3. Genetically modified stress-tolerant rhizobia. . .11

4. Legume plants for the reclamation of marginal soils.13

4.1. Selection of new legumes and the breeding of old traits. ...........................

4.2. Transgenic legumes with enhanced stress tolerance. . . . . . . . . . . . . . . . . . 14

5. Conclusions and prospects. . . . . . . . . . . 16

6. Acknowledgements. . . . . . . . . . . . . . . . . . 17

7. References . . . . . . . . . . . . . . . . . 17 


\section{Introduction}

Over recent decades, anthropogenic activities such us urban development, road construction, industrial processes, mining, and inadequate agricultural practices have resulted in the eutrophication and pollution of soils and fresh water resources, soil degradation, loss of soil fertility, and desertification (McLauchlan 2006; Spiertz 2010; Gordon et al. 2010). Agriculture management, including activities such as tillage, fertilization, and biomass alteration, has a critical impact on food and environmental quality (McLauchlan 2006). In addition, arid and semi-arid regions are particularly prone to salinization, which might occur naturally or as a consequence of mismanaged irrigation, a process that has a profoundly negative effect on crop production (Szabolcs 1994). In fact, almost $40 \%$ of the world's land surface is affected by salinity-related problems (Zahran 1999). Nutrient depletion and soil acidification are two other common consequences of inadequate soil management (Hungria and Vargas 2000). Nitrogen is an essential nutrient for plant growth, and its availability is one of the most limiting factors in agricultural systems. For decades, nitrogen fertilizers have been continuously used to improve crop yield. However, the use of nitrogen fertilizers accelerates the depletion of large amounts of fossil, nonrenewable energy resources, and it contributes substantially to environmental pollution through atmospheric emission and leaching of nitrogenated compounds to ground or surface water (Bohlool et al. 1992; Peoples and Crasswell 1992; Velthof et al. 2009).

Sustainable agriculture involves ecological management, which implies considering elements, such as biodiversity, nutrient cycling, and energy flux, in order to avoid the loss of nutrients and soil and to prevent the attack of pests and diseases (Spiertz 2010). Biological nitrogen fixation, that is, the assimilation of atmospheric nitrogen in form of organic compounds, is a sustainable source of nitrogen in cropping systems, as fixed nitrogen can be used directly by the plant, and it is less susceptible to volatilization, denitrification, and leaching (Jensen and Hauggaard-Nielsen 2003; Garg and Geetanjali 2007). Thus, biological nitrogen fixation in agrosystems can mitigate the use of fertilizers and consequently reduce global warming and water contamination (Bohlool et al. 1992). Nitrogen fixation (diazotrophy) is an exclusive property of prokaryotic organisms containing the nitrogenase enzyme complex. Diazotrophs include some archaea and within the eubacteria, members of proteobacteria, cyanobacteria, actinobacteria, and others. Eukaryotic organisms cannot fix nitrogen, and as such, different types of symbiotic interactions have been established between certain eukaryotes and diazotrophic bacteria. These associations range from loose interactions to highly regulated intracellular symbioses, whereby eukaryotic organisms supply nutrients and energy to the diazotrophs in exchange for fixed nitrogen (Kneip et al. 2007).

The most important nitrogen-fixing agents in agricultural systems are the symbiotic associations between legumes and the group of soil bacteria collectively designated as rhizobia. Rhizobia are a group of diazotrophs, most of them belonging to the $\alpha$-proteobacteria, that include the genera Rhizobium, Mesorhizobium, Ensifer (formerly Sinorhizobium), Bradyrhizobium, Azorhizobium, Methylobacterium, Devosia, Ochrobactrum, Phyllobacterium, and Shinella. Some nodulating bacteria within the genera Burkholderia, Cupriavidus, and Herbaspirillum included in the $\beta$-proteobacteria class have also been described (Masson-Boivin et al. 2009 and references therein; Weir 2009). In conditions of limited nitrogen availability in the soil, specific recognition between the plant and the microsymbiont takes place by signal molecule exchange: legume plants secrete flavonoids and other compounds to the rhizosphere, inducing the rhizobial lipo-chitooligosaccharides, the so-called Nod factors (Cooper 2007). These molecules act as mitogens and the cell division they induce in the root cortex leads to the formation of a new organ, the root nodule, involving the progressive differentiation of specialized cells and tissues. Concomitant with the development of the nodule primordium, bacteria enter the root cortex and in most cases, they form intracellular infection threads in root hair cells that grow inwardly until reaching the nodule primordium cells. The rhizobia infect cells of the nodule primordium entering the nodule host cell by an endocytosis-like process (González-Sama et al. 2004), becoming surrounded by a host-derived membrane. The intracellular bacteria and enveloping membrane becomes known as the symbiosome (Brewin 1991; Jones et al. 2007), which is the basic nitrogen-fixing unit of the nodule. Subsequently, transport of reduced carbon compounds from the plant to the nodule and of fixed nitrogen from the bacteroids to the host plant cytoplasm occurs. Many other metabolites are also exchanged (Udvardi and Day 1997; Hinde and Trautman 2002).

Legumes are second to grasses in their importance to humans and among grain crops, legumes rank third behind cereals and oilseeds in world production. It is estimated that about $88 \%$ of legume species examined to date can form nitrogen-fixing nodules with rhizobia, being responsible for up to $80 \%$ of the biological nitrogen fixation that takes place in agricultural settings. Owing to this capacity, legumes are a major source of food, fodder, timber, phytochemicals, phytomedicines, nutriceuticals, and nitrogen fertility in agrosystems (Graham and Vance 2000, 2003). Thus, legumes may play a key role in sustainable agriculture. Most importantly, mineral nitrogen deficiency is an important limiting factor for plant growth in arid and semi-arid regions, and rhizobia-legume symbioses are the 
primary source of fixed nitrogen in such areas (Zahran 1999). Nitrogen rhizodeposition by legumes occurs by death and decomposition of nodules and roots and by exudation of soluble nitrogen compounds. Rhizodeposition of nitrogen, as a percentage of total plant nitrogen, can vary from $4 \%$ to $71 \%$ (Fustec et al. 2010, and references therein). Exudation of amino acids into the rhizosphere helps prevent loss of organic matter from the soil (Brophy and Heichel 1989). Legume-based pastures can rehabilitate degraded land by improving soil aggregation and by stimulating the activity of different soil organisms that modify soil structure (Parker 1986; Karlen et al. 1994). Legume cover crops also help prevent erosion during the establishment of the plantation (Giller and Wilson 1991). Some legumes, such as alfalfa, have deep roots able to absorb nutrients and water that are not available to other crop plants (Karlen et al. 1994). Phosphorus availability is another limiting factor in many agrosystems. Symbiotic nitrogen fixation and ammonium assimilation induce soil acidification (Raven 1986), which may benefit alkaline soils by solubilizing phosphorus from rock phosphates (Israel and Jackson 1978). Some legumes, such as lupin, can secrete organic anions into the soil, hereby inducing phosphorus solubilization in phosphorus-deficient soils (Weisskopf et al. 2009).

It has long been known that cereals, oilseeds, grasses, and herbs produce higher protein grains and higher yields when grown after or in conjunction with legumes (Dakora and Keya 1997; Jensen and Hauggaard-Nielsen 2003; Danga et al. 2009). Accordingly, legumes are frequently rotated with non-legume crops such as cereals. Intercropping legumes and cereals annually may be beneficial to the environment because it permits more efficient exploitation of the available nutrients, leading to a better use of nitrogen in the agrosystem and reducing post-harvest nitrogen availability and nitrate leaching. Intercropping can also reduce pests and diseases as well as the use of fertilizers and pesticides (Jensen and Hauggaard-Nielsen 2003).

The benefits of nitrogen fixation by legumes are summarized in Fig. 1. In conclusion, the introduction of legumes and their nodulating rhizobia can have an

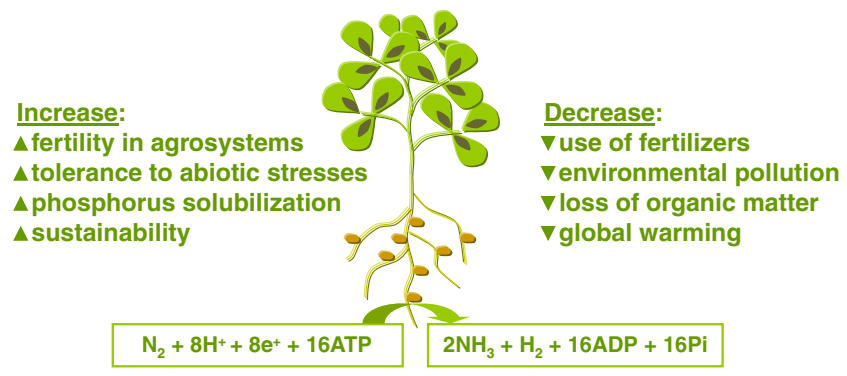

Fig. 1 Some benefits of nitrogen fixation by legumes important effect on the reclamation of degraded and marginal soils for sustainable agriculture. Such recovery is becoming an urgent matter due to the increasing extension of salinized land and the ever-rising requirements for food and feed. Both rhizobia and legumes have a low or moderate tolerance to abiotic stresses. Moreover, symbiosis and nodule functions are very sensitive to abiotic stresses, more so than the host legume or the rhizobia (Delgado et al. 1994; Serraj et al. 1997). Thus, it is of interest to obtain bacterial inocula and legume varieties with enhanced tolerance to abiotic stresses for use in soil reclamation, which can be achieved by traditional trait selection or by biotechnological procedures. We will review here the current research into the physiological and molecular events involved in the response and tolerance to environmental stresses in legumes, rhizobia, and the Rhizobium-legume symbiotic system. Elucidating the physiological and molecular mechanisms that determine sensitivity or tolerance to abiotic stress in this biological system can help establish different strategies to obtain rhizobia, legumes, and nodulated legumes with enhanced tolerance to environmental stresses that act efficiently in reclaiming marginal soils. In the subsequent sections, we will report on recent research concerning the isolation, characterization, and selection of tolerant rhizobial strains and legumes both by traditional methods and biotechnological approaches.

\section{The Rhizobium-legume symbiosis under environmental constraints}

\subsection{Effects of abiotic stresses on free-living rhizobia}

The sensitivity of different rhizobial species and strains to abiotic stress varies considerably (Hungria and Vargas 2000; Vriezen et al. 2007). Salt stress affects both bacteria and plants in two ways: it induces ionic stress due to the high concentration of ions and also osmotic stress through the change in the solute concentration around the cells, producing water deficit and desiccation. It has been reported that fast growing rhizobia are more salt-tolerant than slow-growing rhizobia (Zahran 1999) and that bacteria subjected to salt stress may undergo morphological alterations. Such alterations include cell expansion and distortion of the cell envelope (Busse and Bottomley 1989). Surface components, some of which are necessary to establish symbiosis, can also suffer changes in a saline environment. Decreasing exopolysaccharide synthesis (Breedveld et al. 1991; Lloret et al. 1998; Vanderlinde et al. 2010), structural alterations, and changes in side chain length of lipopolysaccharides (Lloret et al. 1995; Soussi et al. 2001; Bhattacharya and Das 2003; Campbell et al. 2003; Vanderlinde et al. 2009), as well as the suppression or 
alteration of periplasmic oligosaccharides that are involved in bacterial osmotic adaptation (Miller et al. 1986; Ghittoni and Bueno 1995) have been reported. Under osmotic stress, the general metabolism of the Rhizobium slows down, and there is a repression of genes involved in the tricarboxylic acid cycle, in the uptake of carbon supply, in glycogen metabolism, in the respiratory chains, and in ribosomal genes (Dominguez-Ferreras et al. 2006). The expression of genes encoding chaperones and elongation factors, as well as genes involved in cell division, are also altered during salt stress (Wei et al. 2004; Miller-Williams et al. 2006).

Compatible solute (osmolyte) intracellular accumulation has been observed in some species of rhizobia when subjected to salt stress. Higher intracellular concentrations of carbohydrates such as sucrose, trehalose, and maltose (Breedveld et al. 1991, 1993; Gouffi et al. 1999), amino acids such as glutamate and proline (Hua et al. 1982; Botsford and Lewis 1990; Ruberg et al. 2003; DominguezFerreras et al. 2006), and imino acids such as glycine betaine (Talibart et al. 1997; Boncompagni et al. 1999), ectoine (Talibart et al. 1994, 1997), and $N$-acetylglutaminyl-glutamine amide (Smith and Smith 1989; Fougère and Le Rudulier 1990) have been reported. It is thought that these substances and others like proline betaine (Alloing et al. 2006) act as genuine osmoprotectants. In fact, betaine, trehalose, and sucrose accumulation increase rhizobial survival during desiccation (Sauvage et al. 1983; Leslie et al. 1995; Streeter 2003). It was postulated that trehalose and glycine betaine are accumulated to prevent starvation rather than to function as osmotic stabilizers (Oren 1999). Moreover, intracellular accumulation of potassium and some polyamines has also been reported (Zahran 1999; Vriezen et al. 2007 and references therein).

High soil temperatures in tropical and semi-arid regions can also stress soil rhizobia, decreasing rhizobial survival (Hungria and Vargas 2000; Rahmani et al. 2009). High-temperature stress induces physiological and genetic modifications in rhizobia, such as plasmid deletion (Trevors 1986) and genomic rearrangements (Soberón-Chavez et al. 1986). Rhizobial cell surface components such as exopolysaccharides and lipopolysaccharides are also altered under high temperature conditions (Nandal et al. 2005), and overproduction of heat-shock proteins has also been observed (Nandal et al. 2005; Vriezen et al. 2007).

Concerning soil acidity stress, the rhizobial microsymbiont is usually the most $\mathrm{pH}$-sensitive partner. The optimum $\mathrm{pH}$ for rhizobial growth is considered to be between 6.0 and 7.0 , and relatively few rhizobia grow well at a $\mathrm{pH}$ below 5.0, although exceptions have been found (Jordan 1984; Graham et al. 1994). It appears that acid $\mathrm{pH}$ tolerance in rhizobia depends on the ability to maintain an intracellular $\mathrm{pH}$ between 7.2 and 7.5, even at an acidic external $\mathrm{pH}$ (Graham et al. 1994). Rhizobia exhibit an adaptive acid tolerance response that is influenced by calcium (Glenn et al. 1999). Indeed, low $\mathrm{pH}$ soils are often associated with increased aluminium and manganese toxicity and reduced calcium availability (Hungria and Vargas 2000 and references therein). A range of genes are essential to regulate intracellular $\mathrm{pH}$ and the growth of rhizobia at low $\mathrm{pH}$, including a two-component sensor regulatory system that is essential to induce the adaptive acid tolerance response (Glenn et al. 1999). Acidity can affect the size and morphology of rhizobia and their potassium content (Watkin et al. 2003). Furthermore, the activation of glutathione synthesis might be essential for tolerance to acid stress (Muglia et al. 2007).

To define the general stress response, gene characterization and expression studies have been performed in rhizobia. In Sinorhizobium meliloti, osmotic stress induces genes involved in the transport of small molecules and polysaccharide biosynthesis, whereas genes related to motility and chemotaxis, amino acid biosynthesis, and iron uptake are repressed (Ruberg et al. 2003). Some genes related to low $\mathrm{pH}$ tolerance were identified in rhizobial strains that nodulate French beans under arid and semi-arid conditions (Priefer et al. 2001). Moreover, several gene loci were identified in Rhizobium tropici that are required for adaptation to high $\mathrm{pH}$ (Nogales et al. 2002). Gene expression during osmotic stress has also been characterized by microarray technology (Ruberg et al. 2003), and the expression patterns of up- and down-regulated genes in response to acidic $\mathrm{pH}$ shifts have been studied in S. meliloti (Hellweg et al. 2009). In addition, a sigma factor was identified and characterized that acts as a general stress response regulator in S. meliloti (Sauviac et al.; 2007; Bastiat et al. 2010).

\subsection{Effects of environmental stress on legumes} and their symbiotic performance

\subsubsection{Plant growth and photosynthesis}

Legumes have long been recognized as either sensitive or only moderately resistant to salinity (Zahran 1991). Legume seed germination is affected by salinity and other stresses, like alkalinity or temperature (Guan et al. 2009). Most legumes respond to moderate salinity by decreasing their growth, both by inhibiting plant cell expansion due to osmotic stress and through cell injury in transpiring leaves and other plant tissues due to the accumulation of $\mathrm{Na}^{+}$and $\mathrm{Cl}^{-}$ions (Delgado et al. 1994; Soussi et al. 1998; Gholipoor et al. 2000; Bayuelo-Jimenez et al. 2003; Ahmad and Jhon 2005; Manchada and Garg 2008). Ion toxicity induces alterations in the acquisition and homeostasis of essential nutrients, such as $\mathrm{K}^{+}, \mathrm{Ca}^{2+}$, and $\mathrm{Mg}^{2+}$, and even in nutrient transport (Jeschke et al. 1992; Manchada and Garg 2008). 
Legumes usually respond to salinity by excluding $\mathrm{Na}^{+}$and/ or $\mathrm{Cl}^{-}$ions and in fact, it is thought that salt tolerance in legumes is related to their ability to avoid salt ion accumulation in the leaves (Winter and Läuchli 1982; Läuchli 1984; Lauter et al. 1988; Teakle et al. 2006; Cabot et al. 2009). A vacuolar $\mathrm{Na}^{+} / \mathrm{H}^{+}$antiporter was recently isolated and characterized that plays an important role in salt tolerance and ion homeostasis in legume Trifolium repens, probably by inducing $\mathrm{Na}^{+}$accumulation into the vacuole (Tang et al. 2010). Almost all metabolic processes are affected by salt and water stress. For example, complex carbohydrates and proteins are broken down by enzymes into simpler sugars and amino acids, respectively (Pandey et al. 1984). Moreover, photosynthesis and the export of photoassimilates from leaves declines upon salt or water stress due to reduced stomatal conductance, reducing transpiration and carbon dioxide entry (Nilsen 1992; Soussi et al. 1998; Iturbe-Ormaetxe et al. 1998; Ohashi et al. 2000; Reddy et al. 2003; Nunes et al. 2009). Disorganization of thylakoid and other cellular structures has also been observed during water and heat stress (Matos et al. 2002).

\subsubsection{Nodule formation, structure, and physiology}

Symbiosis and nodule functions are very sensitive to salt stress, more so than the host legume or the rhizobia (Delgado et al. 1994; Serraj et al. 1997; Zahran 1999 and references therein). Salinity clearly affects nodule formation and nitrogen fixation earlier and more severely than plant growth (Verdoy et al. 2004; Fig. 2). Salt stress reduces the number of rhizobia that colonize the root (Tu 1981), as well as the number and shape of root hairs, and it interferes with infection thread formation (Zahran and Sprent 1986). The initial phases of nodulation are more sensitive to salt or acid stress than later phases (Singleton and Bohlool 1984; Ikeda 1994; Miransari et al. 2006). Under conditions of acidity and high temperature, the release of Nod factors by rhizobia and/or the release of nod-gene inducers from the legume roots decreases (Hungria 1995; Hungria and Stacey 1997; Hungria and Vargas 2000). High temperature also inhibits root hair formation, adherence of bacteria to root hairs, the formation of the nodule primordium, and release from the infection thread and bacteroid development (Hungria and Vargas 2000 and references therein). Salt stress induces a decrease in nodule weight and number (El-Sheikh and Wood 1990; Cordovilla et al. 1999).

Salt stress induces morphological and ultrastructural alterations in the nodule, including cytoplasm disintegration and loss of cell wall rigidity, a decrease in the packaging of inner cortex cells, the appearance of lobulated nuclei, variations in chromatin condensation, a decrease in the volume of intercellular spaces, and an increase in the

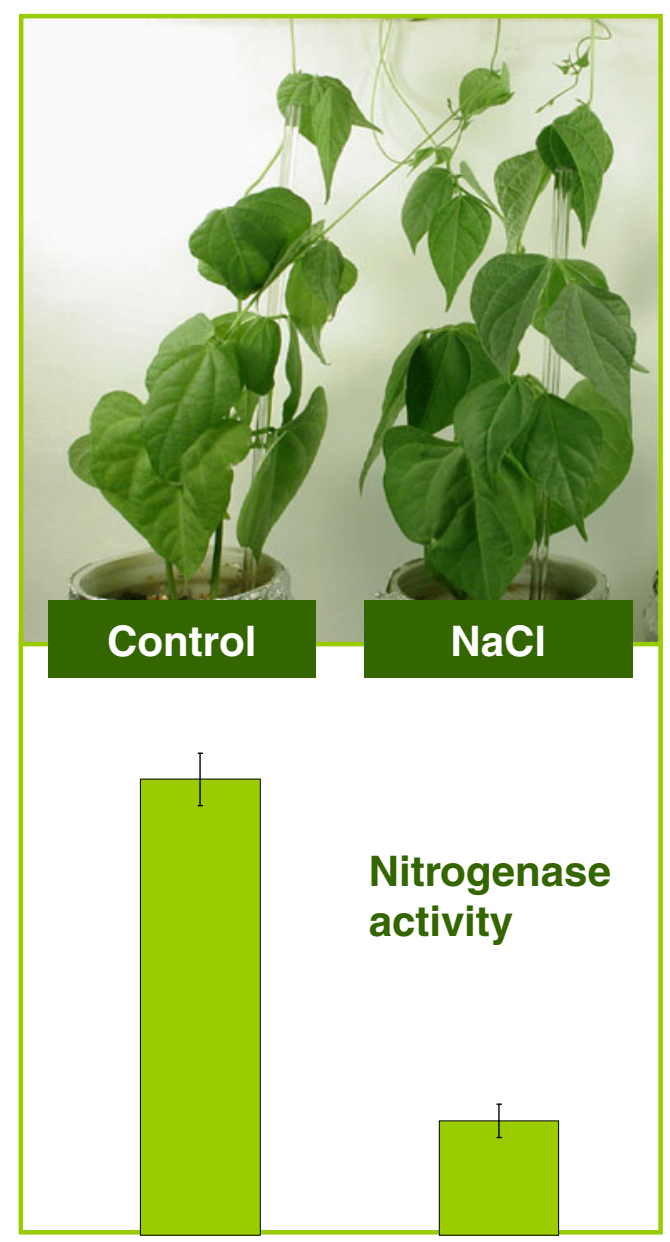

Fig. 2 The nitrogen-fixing activity is more sensitive to salt stress than the legume plant

epidermis and cortex membrane surface due to increased numbers of vesicles (Swaraj and Bishnoi 1999 and references therein; Coba de la Peña et al. 2003 and references therein; Borucki and Sujkowska 2008).

Nodule function is affected by mild stress earlier and more severely than photosynthesis (Djekoun and Planchon 1991). Nitrogenase catalyzes the fixation of atmospheric dinitrogen into ammonia, and its enzymatic activity is inhibited by free oxygen. A microaerobic environment is present in the nodule due to the combined action of the oxygen diffusion barrier in the nodular inner cortex and leghemoglobin, which transports and supplies oxygen to bacteroids for respiration. A decrease in nitrogen fixation, nitrogenase activity, and respiration, and an increase in fermentative activity have been observed in nodules subjected to salt and drought stress. It is thought that this effect is principally due to the decrease in oxygen permeability at the oxygen diffusion barrier in stressed nodules (Swaraj and Bishnoi 1999) and to a decrease in leghemoglobin levels (Delgado et al. 1994). In fact, salt tolerance of different legume varieties has been associated 
with stability in nodule conductance (Aydi et al. 2004; L'taief et al. 2007). High temperature also decreases the synthesis of leghemoglobin and nitrogenase activity (Hungria and Vargas 2000 and references therein). Simulation models to estimate nitrogen fixation rates with several biotic and abiotic factors, including drought and high temperature, have been developed (Liu et al. 2010). The mechanisms by which the diffusion barrier regulates and changes the conductivity of oxygen under different environmental conditions have not been clearly elucidated. It seems that there is a correlation between those changes and cellular elongation and glycoprotein extrusion in the extracellular spaces of the inner cortex (Hunt and Layzell 1993; Iannetta et al. 1995). Ultrastructural modifications induced by salt or chilling stress have also been observed in the nodule cortex and infected zone (Serraj et al. 1995; Van Heerden et al. 2008).

Plant adaptation to saline stress involves a transient increase in the level of hormone abscisic acid (ABA). In conditions of drought, salinity, and cold, ABA mediates the closure of stomatal pores to limit water loss by transpiration, and it confers tolerance to desiccation (Montero et al. 1997; Leung and Giraudat 1998). Auxins, such as indole-3acetic acid (IAA), are other hormones involved in the early steps of nodule organogenesis (Ferguson and Mathesius 2003). Aldehyde oxidases (AOs) are enzymes involved in the last steps of ABA and IAA synthesis and therefore, they might regulate many aspects of plant growth, development, and adaptation to a variety of stresses. Recently, several AO genes were identified in Pisum sativum, and some of them are induced by salt and/or ammonium stress (ZdunekZastocka 2008). AO transcript accumulation and enzymatic activity has been determined in nodules of Medicago truncatula and Lupinus albus (Fedorova et al. 2005). Cytokinins are another hormone type involved in the establishment of legume-Rhizobium symbiosis and the early steps of nodule organogenesis. Together with auxins and nodulins (legume genes involved in nodulation), cytokinins induce mitotic activity in root cortical cells, leading to the formation of the nodule primordium (Ferguson and Mathesius 2003). Cytokinins are thought to have a protective effect on plants under stress (Chernyad'ev 2009). Cytokinins are sensed by hybrid-type histidine kinases and transduced by a two-component signaling system that involves a His-Asp phosphorelay (Kakimoto 2003 and references therein). In legumes, some members of the cytokinin receptor multigenic family are essential for nodulation (Murray et al. 2007), and cytokinin receptors are involved in nodule morphogenesis, senescence, and stress response (Coba de la Peña et al. 2008a, b). In Arabidopsis, cytokinin receptors act as negative regulators during abiotic stress and in ABA signaling, and they probably participate in signaling cross-talk involving cytokinins, ABA, and stress-signaling pathways (Tran et al. 2007; Coba de la Peña et al. 2008c and references therein).

Sucrose availability may also be an important factor involved in the inhibition of nitrogen fixation, as nitrogenase activity has been correlated with a decrease in sucrose synthase activity and transcript levels in nodules under conditions of drought and other environmental stress (Gordon et al. 1997; Arrese-Igor et al. 1999). Nitrogen assimilation is also affected by reducing glutamine synthetase and glutamate synthase activities (Hungria and Vargas 2000). Ascorbate and ascorbate peroxidase activities also seem to be important in regulating nitrogenase activity and dinitrogen fixation in legumes (Ross et al. 1999). Indeed, nodule nitrogen fixation appears to be inhibited by feedback regulation of ureide accumulation in the shoot during drought stress (Serraj et al. 1999), and a decrease in the activity of the enzymes involved in ammonium assimilation and in photosynthate influx into the nodule have also been observed in nodules subjected to salt stress (Coba de la Peña et al. 2003 and references therein).

Plants, like rhizobia, accumulate compatible solutes as an adaptive mechanism to salt stress. These include nonstructural carbohydrates (sucrose, hexose), sugar alcohols (mannitol, ononitol, and sorbitol), amino acids (proline, alanine, arginine, glycine, and others), betaine and betainederived molecules (glycine betaine), and amides (glutamine, asparagine) (Keller and Ludlow 1993; Ashraf and Waheed 1993; Ashraf 1994; Schubert et al. 1995; Márquez et al. 2005; Manchada and Garg 2008). Proline is probably the most widely distributed osmolyte (Delauney and Verma 1993), and a strong correlation between osmolyte accumulation and osmotic stress tolerance has been widely reported (Zhu 2002). Legume symbiotic nodules subjected to salt or drought stress accumulate proline, other amino acids, sugars, and other osmolytes (Fougère et al. 1991; Fernández-Pascual et al. 1996; Swaraj and Bishnoi 1999; Larrainzar et al. 2009). Proline accumulation in the symbiosome has also been reported (Pedersen et al. 1996), and the accumulation of transcripts for proline-rich proteins has been observed in saltstressed nodules (Verdoy et al. 2004). In order to explain the effect of compatible solutes, it is suggested that these molecules induce an osmotic adjustment, inducing a decrease in osmotic potential to allow an increase in water absorption and a re-establishment of intracellular salt concentration (Chen and Murata 2002). Other mechanisms against stress that have been proposed for these solutes, particularly for proline, include protection of plasma membrane integrity, providing an energy sink or reducing power, a source of carbon and nitrogen, protection of enzymes against denaturation by direct molecular interaction, heavy metal detoxification, and a signaling/regulatory role that might activate multiple responses (Rai 2002 and references therein). 
The generation of toxic reactive oxygen species (ROS) is an unavoidable consequence of aerobic metabolism. ROS include, among others, hydrogen peroxide, superoxide ion, the strongly toxic hydroxyl radical, and nitric oxide. Oxygen species are principally generated in mitochondria and chloroplasts as a consequence of the electron transport associated with respiration and photosynthesis, respectively. During stress, increases in ROS generation occur due to altered metabolism within these organelles. It has been proposed that ROS induce oxidative damage in several cellular components, affecting proteins, nucleic acids, and membrane lipids. ROS play also a role in orchestrating plant gene expression and regulation (Foyer and Graham 2009; Chang et al. 2009). The legume nodule is very sensitive to ROS, where oxidative stress by ROS induces an array of toxic effects and triggers nodule senescence. Salt stress induces nodule senescence through the enhanced production of toxic ROS and the lowering of antioxidant defenses (Gogorcena et al. 1995; Sheokand et al. 1995; Swaraj and Bishnoi 1999). Nodule natural senescence also involves an increase in ROS and a decrease in antioxidant levels (Evans et al. 1999; Hernández-Jiménez et al. 2002; Puppo et al. 2005). Nodules are rich in leghemoglobin, which can undergo autoxidation and generate ROS (Puppo et al. 1981; Dalton et al. 1986). ROS induce leghemoglobin and protein degradation, originating protein radicals and catalytic iron (Davies and Puppo 1992) that induce lipid peroxidation, as well as generating hydroxyl radicals and glutathione oxidation, which in turn produce superoxide and oxygen peroxide (Puppo and Halliwell 1988; Becana et al. 1998). Hydroxyl radicals can damage sugars, lipids, proteins, and DNA. The presence of specific proteins related to nitrogen fixation in the nodule that are susceptible to autooxidation, such as ferredoxin, uricase, and hydrogenase, can also induce ROS generation (Dalton et al. 1991). Plants have developed several antioxidant systems to scavenge ROS that are also active in symbiotic nodules (Dalton et al. 1986, 1993; Evans et al. 1999; Becana et al. 2000; Matamoros et al. 2003; Puppo et al. 2005). These include the enzymes catalase, superoxide dismutase (SOD) and peroxidase, as well as the ascorbateglutathione pathway, which includes ascorbate peroxidase, monodehydroascorbate reductase, dehydroascorbate reductase, and glutathione reductase (Dalton et al. 1986, 1992; Noctor and Foyer 1998; Becana et al. 2000). Lowmolecular weight antioxidants ascorbate and reduced glutathione in this pathway can also scavenge superoxide and hydrogen peroxide (Becana et al. 2000; Matamoros et al. 2006; Loscos et al. 2008). In some legume species and tissues, glutathione is partially or completely replaced by homoglutathione, which presumably fulfils analogous functions (Evans et al. 1999; Loscos et al. 2008).
Several recent studies have used molecular techniques, including transcriptomics, proteomics, and metabolomics, to define new genes, proteins, and metabolites involved in abiotic stress in legumes. In this way, a set of differentially expressed genes was identified during heat-shock treatment of cowpea nodules (Simões-Araújo et al. 2002). Similarly, expressed sequence tags (ESTs) have been analyzed in drought-tolerant horsegram under various abiotic stress conditions (Reddy et al. 2008), and a transcriptome study was performed on alfalfa subjected to drought stress (Chen et al. 2008). ESTs have also been characterized in pigeon pea subjected to water deficit conditions (Priyanka et al. 2010), as have drought and salinity responsive ESTs in chickpea (Varshney et al. 2009; Jain and Chattopadhyay 2010). Drought-induced genes were studied in peanut (Govind et al. 2009) and microRNAs were identified in Phaseolus vulgaris subjected to drought (Arenas-Huertero et al. 2009). A gene expression atlas of M. truncatula was obtained by comparative transcriptome analysis as a resource for legume functional genomics (Benedito et al. 2008), and gene expression was analyzed in the roots of $M$. truncatula subjected to salt stress (Merchan et al. 2007; Li et al. 2009). The model legume Lotus japonicus has been exposed to salt stress, and profiles were obtained at the ionomic, transcriptomic, and metabolomic levels, in order to perform integrative functional genomics (Sanchez et al. 2008). The characterization of genes and regulatory pathways involved in legume tolerance to abiotic stresses will allow the mechanisms of stress tolerance in legumes to be elucidated. These results hold promise for the future engineering of legume crop plants with enhanced tolerance to major abiotic stresses.

\section{Rhizobial inoculants in the reclamation of marginal soils}

The fact that nitrogen fixation is an essential aspect of agricultural sustainability has led to the development of different strategies to maximize legume-derived nitrogen fixation in agriculture: field inoculation with selected rhizobial strains; growth of selected legume species and varieties; and the selection and joint field application of both bacteria and legumes. In this section, we will review the current research concerning the identification and selection of rhizobial strains with suitable characteristics for field inoculation to induce legume nodulation and nitrogen fixation under environmental constraints. We will also review the existing knowledge on the role of rhizobia as endophytes and plant growth-promoting rhizobacteria, both in leguminous and non-leguminous plants. Finally, research concerning the development of genetically engineered stress-tolerant rhizobia will be examined. 
3.1 Selection of rhizobial inoculants that nodulate legumes in stressed environments

Nodulation, nitrogen fixation, and growth can be improved in legumes by inoculating plants with competitive and stress-tolerant rhizobia. This is an economically feasible way to increase legume production in stress-limited environments, particularly when local rhizobia strains are absent from soils or ineffective (Zahran 1999 and references therein). An inoculant strain must display enhanced competitive ability to successfully colonize plant roots, form nodules, and subsequently perform nitrogen fixation. Thus, complex interactions between the edaphic environment with genotypes of both the legume and its microsymbiont must be taken into account, and different strategies have been developed to select quality inoculant rhizobial strains to enhance legume-derived nitrogen fixation in agriculture (Sessitsch et al. 2002 and references therein). Different legume inoculation techniques have been developed, such as slurry, lime or phosphate pelleting, vacuum impregnation for seed inoculation, and liquid and granular inoculation for soil inoculation (Brockwell and Bottomley 1995; Deaker et al. 2004).

Molecular and phylogenetic studies have been performed in order to classify and evaluate the molecular diversity of rhizobia (Wang and Martínez-Romero 2000; Lloret and Martínez-Romero 2005; Mouhsine et al. 2007; Elboutahiri et al. 2009; Binde et al. 2009), providing a suitable means to identify and manage rhizobial isolates. Evaluating rhizobial competition in the rhizosphere must also be performed, and several specific determinants of competitive nodulation have been identified. One such factor is the secretion of rhizopines, myo-inositol derivatives by various $S$. meliloti and Rhizobium leguminosarum bv. viciae strains. Nodule bacteroids from these strains can synthesize rhizopines, which are subsequently catabolized by the corresponding free-living rhizobial strain and a few other bacteria. Studies of competition have shown that in the presence of a rhizopine-producing strain, the strain that can catabolize the rhizopine occupies a higher percentage of the nodules (Murphy et al. 1995 and references therein). However, to date, the mechanism and biological functions of rhizopines remain unclear. Another determinant of competitive nodulation is the production of trifolitoxin, a potent antirhizobial peptide that is produced by some $R$. leguminosarum strains (Triplett and Barta 1987). Similarly, $R$. leguminosarum strains can also produce bacteriocins, antibiotics that are active against closely related strains or species (Oresnik et al. 1999; Yajima et al. 2008). As explained above, the physiology of the bacterial surface may also be a competitive factor, and the competitive capacity of rhizobial mutants with altered lipopolysaccharides or exopolysaccharides may be altered (Fraysse et al. 2003; Ormeño-Orrillo
2005). For example, the production of exopolysaccharides is influenced by a complex network of environmental factors such as phosphate, nitrogen, or sulphur (Skorupska et al. 2006). Finally, genetic exchange among rhizobia in the soil and the often reported genome instability of Rhizobium may affect competitiveness (Ding and Hynes 2009; OrozcoMosqueda et al. 2009). Understanding these and other factors might facilitate the development of different approaches to manipulate rhizobial competition (Sessitsch et al. 2002 and references therein).

We shall now focus on some of the recent research aimed at identifying rhizobial strains of interest and/or that has focused on their use as inocula for legume nodulation in marginal soils. Numerous studies have characterized the effectiveness of different inoculants, and their competition with indigenous strains has been determined. As such, field inoculation of the common bean with selected $R$. tropici strains induced nodulation and improved nitrogen fixation rates, even in presence of high indigenous rhizobial populations (Hungria et al. 2003). Moreover, the composition of the indigenous bacterial community was not clearly affected by massive inoculation of selected strains. Several indigenous rhizobial isolates with higher nitrogen fixation effectiveness than some commercial inoculants have been isolated and characterized (Zengeni and Giller 2007), some of which are proposed to be new potential commercial inoculants. A Rhizobium gallicum strain selected for its competitiveness and symbiotic effectiveness was used to nodulate common bean, inducing an increase in nodule number and plant shoot dry weight, even in a soil with a high population density of indigenous $R$. gallicum (Mnasri et al. 2007). It is also interesting that this selected inoculum produces antimicrobial activity against indigenous common bean rhizobia. Studies of competition between introduced and native $R$. leguminosarum strains have been performed for nodulation of $T$. repens and Trifolium pratense in Uruguay (Blanco et al. 2010). Interestingly, pre-treatment of red clover seeds with specific Nod factors significantly enhanced clover nodulation by an inoculant strain and the subsequent growth of plants in the soil (Maj et al. 2009).

Improved legume production, particularly in arid and semi-arid areas, requires the selection of effective rhizobial strains. P. vulgaris and other food legumes are frequently grown in rotation with cereals. Up to 30 osmotolerant strains of Rhizobiaceae have been isolated and characterized from Moroccan saline soils in order to use them as inoculants to improve common bean production in these soils (Bouhmouch et al. 2001). In greenhouse experiments, a comparative analysis of inoculation of $P$. vulgaris cultivars was performed with reference rhizobial strains and local isolates (Aouani et al. 1997), identifying certain improvements following inoculation with selected strains. Salt-tolerant rhizobia that were able to nodulate chickpea 
(Cicer arietinum) were characterized and selected in conditions of water deficiency (Romdhane et al. 2008; 2009) and inoculation with selected salt-tolerant rhizobia significantly increased nodule number and grain yield of this pulse legume in the field. In some cases, improvement in plant production was equal to or better than that of nitrogen fertilization. Rhizobial species and strains isolated from wild herbs and tree legumes from arid regions often have a wide host range and are very tolerant of salinity, high temperature, and desiccation. Such species hold potential to inoculate wild and crop legumes cultivated in reclaimed arid lands (Zahran 2001 and references therein).

The genetic diversity and symbiotic efficiency of different rhizobial isolates obtained from nodules of peanut (Arachis hypogaea) in Morocco has also been characterized (El-Akhal et al. 2008). Isolates were grouped with species belonging to both the Bradyrhizobium and Rhizobium genera, and their phenotypic and genotypic characterization allowed them to be classified in two groups: alkali- and salt-sensitive slow growers and alkali- and salt-tolerant fast growers (El-Akhal et al. 2009). Both groups exhibited variability in their tolerance of heavy metals, and wide genotypic diversity was observed at the strain level. In arid and semi-arid regions of Morocco, strains of $S$. meliloti and Sinorhizobium medicae were isolated that were tolerant to salinity, water stress, high temperature, acidity, and heavy metals, and the genetic diversity of these strains was studied (Elboutahiri et al. 2010). This kind of characterization provides a basis for selecting nodulating rhizobia that may have applications in formulating appropriate inocula to improve legume crop yield in stress-affected soils, including marginal saline and acidic areas. Rhizobial strains were also isolated from leguminous shrubs in semi-arid soils of Central Spain (Ruiz-Díez et al. 2009), several of which displayed salinity, acidity, alkalinity, and cadmium tolerance. The diversity and phylogeny of rhizobial bacteria associated to nodules of the shrub legume Ononis tridentata have also been characterized in Spanish soils (Rincón et al. 2008). This shrub legume is highly prized for the revegetation of gypsum soils in semi-arid Mediterranean areas and thus, this molecular characterization has implications for formulating suitable bacterial inocula to recover gypsum ecosystems. The persistence of two Rhizobium etli strains that nodulate beans in clay soil and silty loam soil from Egypt was also established (Moawad et al. 2005).

In Brazil, numerous efficient nitrogen-fixing rhizobia have been selected to nodulate legume trees in order to revegetate poor or depleted soils and to restore their fertility (Franco and De Faria 1997). In Australia, extensive clearing of native vegetation has contributed to major environmental problems, including land degradation, dryland salinity, soil erosion, and loss of biodiversity. A low-cost revegetation approach has been to inoculate different native leguminous shrubs and trees with elite strains of native rhizobia in order to re-establish plant-soil interactions in degraded lands (Thrall et al. 2005). The diversity and salt tolerance of native isolated rhizobia nodulating Acacia has also been characterized in saline and non-saline Australian soils (Thrall et al. 2009), and rhizobial populations derived from saline soils had higher salt tolerance and grew better. A Mesorhizobium sp. strain with high tolerance to salinity, $\mathrm{pH}$, and temperature and that displayed a wide host range of nodulation, was isolated and characterized from a semi-arid region of northwestern China (Wei et al. 2008).

Acidity is an increasing problem in tropical and arid soils, and it was seen that rhizobia isolated from acid soils were significantly more tolerant to acidity than isolates from neutral soils (Gemmell and Roughley 1993). Indeed, an acid-tolerant $R$. leguminosarum strain has been selected that had higher nodule occupancy at low $\mathrm{pH}$ in different bean cultivars than an acid-sensitive strain (Vargas and Graham 1989). Mesorhizobium isolated from Portuguese soils that were able to grow at acid $\mathrm{pH}$ could be used to develop highly effective inoculants for chickpea in acid soils (Brigido et al. 2007). The genetic diversity of alfalfa rhizobia isolated from volcanic soils in southern Chile was evaluated, and several acid-tolerant $S$. meliloti strains with high symbiotic effectiveness under acidic conditions were identified and characterized (Langer et al. 2008). In field experiments to evaluate the potential Rhizobium inoculants suitable for pulse legume production in acidic soils of South-East Australia storage, temperature and humidity conditions were established to maintain the viability of the inoculant (Evans 2005). Field competition experiments have been carried out in Southern Spain and different inoculant strains of Sinorhizobium fredii were selected that can nodulate soybean in alkaline or acid soils (Albareda et al. 2009). Halotolerant and desiccation-resistant rhizobial strains nodulating Acacia were isolated from Moroccan desert soil, and tolerant and sensitive strains accumulated different types of endogenous osmolytes (Essendoubi et al. 2007). Novel strains of the $\beta$-proteobacteria Burkholderia capable of nodulating an herbaceous legume, Rhynchosia ferulifolia, and with a potential role in nitrogen fixation adapted to acid, infertile soils were characterized (Garau et al. 2009).

High temperatures diminish rhizobial survival and establishment in tropical soils. Repeated inoculation of soybean compensates the detrimental effects of high temperatures and increases nodulation, nitrogen fixation rates, and crop yield in Brazil (Vargas and Hungria 1997). In tropical Brazilian soils, nodulation of common bean and other legumes is usually poor, this failure being attributed to high soil temperature, and rhizobial temperature tolerance is not always closely related to the 
geographical origin of a strain (Hungria and Vargas 2000 and references therein). Different studies have shown that $R$. tropici tolerates significantly higher temperatures than other rhizobia like $R$. leguminosarum and $R$. etli. Moreover, $R$. tropici is genetically more stable, maintaining symbiotic properties under stress (Martínez-Romero et al. 1991; Hungria et al. 1993), which makes it very interesting for inoculation programs. Thermotolerant bradyrhizobial strains have been isolated to perform nodulation of soybean in semi-arid regions of Iran (Rahmani et al. 2009) and in the greenhouse, some of the thermotolerant isolates displayed good nitrogen-fixing activity even at $38^{\circ} \mathrm{C}$.

In terms of reclamation or bioremediation of different types of contaminated soils, efficient strains of Bradyrhizobium sp. were isolated from mine spoils and used to inoculate seeds of the legume Albizia lebbeck grown in both gypsum and limestone mine spoils (Rao and Tak 2001). Improved nodulation and nitrogen-fixing activity was observed, and therefore, this system may be useful for revegetation of mine spoils. Indigenous toluate-tolerant bacteria were isolated from the oil-contaminated rhizosphere of Galega orientalis, and they constitute a potential system for bioremediation of oil-contaminated soil (Lindström et al. 2003). It has also been reported that wastewater sludge, a worldwide recyclable waste, has good potential for rhizobial inoculant production, both as a growth medium and as a carrier source for inoculant production (Ben Rebah et al. 2007).

3.2 Rhizobia as endophytes and plant growth promoting rhizobacteria in legumes and non-legumes

In non-nodulating legumes, rhizobia have been encountered inside roots without forming nodules (Allen and Allen 1991). Indeed, rhizobia have also been found as common rhizosphere colonizers of a wide range of plants and also as endophytic bacteria in legumes and non-leguminous plants such as rice, sugarcane, wheat, and maize (Sessitsch et al. 2002 and references therein). It has been shown that rhizobia can successfully colonize the mainstream roots, stems, and leaves of non-leguminous plants, and in many cases, these endophytic rhizobia benefit the host through plant growth promotion (PGP), producing a marked increase in plant growth, vigor and yield, and stress tolerance (Sessitsch et al. 2002; Hossain and Martensson 2008; Bhattacharjee et al. 2008 and references therein; Bano and Fatima 2009). In exchange, endophytes enjoy a more favorable environment than rhizospheric bacteria, being protected from stress and enjoying the direct provision of nutrition within the host (Sevilla and Kennedy 2000). The traditional legume (berseem clover)-cereal (rice) association in Egypt involves an endophytic activity of $R$. leguminosarum, which induces PGP in rice. Moreover, inoculation of $R$. trifolii to a rice variety significantly increases its total nitrogen content and grain yield (Yanni et al. 1997, 2001; Biswas et al. 2000a, b). Examples of endophytic or rhizospheric rhizobia associations with nonleguminous plants are reviewed and listed in Sessitsch et al. (2002) and Bhattacharjee et al. (2008).

The entry of endophytic rhizobia takes place through root tips, lateral root cracks, sites of injury, and damaged stomata. Infection thread-like structures have also been observed in inoculated plants. It seems that bacteria colonize intercellular spaces of root cortex and extend to the xylem vessel for further propagation, and they can propagate to the next plant generation through the seeds (Bhattacharjee et al. 2008 and references therein). There are several propositions to explain the PGP effects of rhizobia on the non-legume host plant. Endophytic rhizobia have been reported to induce nitrogen accumulation in the host plant, which may be due to nitrogen fixation by rhizobia (Oliveira et al. 2002) or an increase in nitrogen uptake from the soil (Yanni et al. 1997). In fact, the expression of nitrogenase was detected in epidermal cells, in the intercellular region of the root cortex and in vascular tissue of the roots of rice and other plants (Egener et al. 1999). Alternatively, the legume or non-legume plant growth stimulation might be due to the production and secretion of plant growth regulators by rhizobia, such as indole-3acetic acid (IAA), gibberellins, and cytokinins (Yanni et al. 2001; Verma et al. 2001; Boiero et al. 2007; Vargas et al. 2009). Endophytic or rhizospheric rhizobia also favor the solubility of phosphorus through the production of phosphate-solubilizing enzymes (Verma et al. 2001). Bacteria also secrete 1-aminocyclopropane-1-carboxylate (ACC) deaminase, which diminishes ACC levels, a precursor of ethylene, thereby reducing the levels of ethylene (Glick 2005; Duan et al. 2009). Rhizobia can also produce strain-specific siderophores that can help overcome iron starvation (Jin et al. 2006; Vargas et al. 2009). In some cases, rhizobia-produced LPS can induce systemic resistance which buffers the deleterious effects of phytopathogens (Reitz et al. 2001).

An increasing number of bacteria other than rhizobia have been identified as rhizospheric and/or endophytic nitrogen fixers in a variety of cereal crops and pasture grasses (Franche et al. 2009, and references therein). Sugar cane is a good example of a crop that can benefit from nitrogen fixation (Boddey et al. 2001, 2003). Other associations with Gramineae and grasses have also been described (Boddey and Döbereiner 1982; Reis et al. 2001). These discoveries suggest that it is possible to increase biological nitrogen fixation in cereal crops by inoculation with wild-type or genetically modified nitrogen-fixing bacteria (Franche et al. 2009). 


\subsection{Genetically modified stress-tolerant rhizobia}

One aim of the genetic engineering of rhizobia (Table 1) is to develop stress-tolerant strains that can be used as inoculants in marginal soils. However, the release of genetically improved strains is often restricted by National regulations. Several studies have been performed on field inoculation with genetically modified rhizobia carrying chromosomally located antibiotic resistance markers in order to study the population dynamics of indigenous and genetically modified rhizobia over a period of several years (Hirsch and Spokes 1994; Hirsch 1996). The luciferase gene-tagged S. meliloti L33 strain has also been used as inoculant in greenhouse and field experiments to evaluate the efficacy of different strategies to eliminate an established population of inoculated Rhizobium when its function is completed (Miethling and Tebbe 2004).

Acid-tolerant strains of $R$. leguminosarum have been constructed with enhanced capacity for nitrogen fixation by replacing the symbiotic plasmid pSym (Chen et al. 1991). Transfer of pSym to a genetically modified strain of $R$. leguminosarum conferred advantages in the rhizosphere by increasing host fitness in the field (Clark et al. 2002). An enhanced salt-tolerant $R$. leguminosarum strain was also obtained by transformation with DNA from a salt tolerant Bacillus species (El-Saidi and Ali 1993), and the plant yield of host legumes nodulated by this strain increased, as did the nitrogen content in arid soils. Transformed $R$. trifolii and $R$. leguminosarum were obtained that constitutively expressed a chimeric nodD gene, involved in the regulation of Nod factor synthesis (Spaink et al. 1989). Legumes nodulated by these transformed rhizobia displayed significantly higher nitrogen fixation. Moreover, in a field experiment, a genetically modified $S$. meliloti strain overexpressing the putA gene, which codes for proline dehydrogenase (an enzyme that catalyzes the conversion of proline present in root exudates to glutamate), has a competitive advantage over natural rhizobial populations with regards to infecting and nodulating alfalfa roots subjected to drought stress (Van Dillewijn et al. 2001, 2002).

A $S$. meliloti recombinant strain was produced that contained additional copies of nifA and $\operatorname{dct} A B D$ genes to increase nitrogen fixation, and thus, the yield of alfalfa (Bosworth et al. 1994). nifA is involved in regulating the expression of nitrogen fixation genes, and $\operatorname{dct} A B D$ genes are involved in the transport of dicarboxylic acids, which are required as a carbon energy source. This recombinant strain has been commercialized and tested in the field, inducing an improvement in biomass yield where soil nitrogen and organic matter content were low. A hemoglobin gene from Vitreoscilla sp. was introduced in $R$. etli, and the recombinant bacteria obtained had greater respiratory activity, chemical energy, and expression of the nitrogen fixation gene nifH. Plants inocu- lated with this recombinant strain had enhanced nitrogenase activity and total nitrogen content when compared with plants inoculated with the wild-type strain (Ramírez et al. 1999). A Rhizobium tropici mutant with enhanced respiration and symbiotic performance was obtained by mutating the glycogen synthase gene (Marroquí et al. 2001).

Symbiotic nitrogen fixation is an energy-consuming process that takes place under microaerobic conditions, since nitrogenase activity is inhibited by oxygen. Terminal oxidase $c b b_{3}$ has an extremely high oxygen affinity, and it is efficiently coupled to ATP production and is essential for nitrogen-fixing endosymbiosis. However, due to the presence of oxygen, the $c b b_{3}$ gene is not usually expressed in the free-living state. $\mathrm{NtrC}$, a transcriptional activator that modulates gene expression in response to nitrogen, represses the free-living cell production of this terminal oxidase. Overexpression of the Bradyrhizobium japonicum terminal oxidase $c b b_{3}$ in a $R$. etli $n t r C$ mutant increased nitrogen fixation (Soberón et al. 1999). S. meliloti strains have been constructed that contain different copy numbers of a symbiotic gene region covering a regulatory gene (nodD1), the common nodulation genes (nodABC), and a gene essential for nitrogen fixation (nif $N$ ). The strains with a moderate increase in copy number of this symbiotic gene region were associated with significantly improved nodulation, nitrogenase activity, plant nitrogen content, and plant growth (Castillo et al. 1999).

Inoculated strains must compete with native soil bacteria for root nodulation. As indicated above, a strategy to alleviate this problem is to produce the anti-rhizobial peptide trifolitoxin. Under field conditions, inoculation of a genetically engineered $R$. etli strain that produces this peptide increased nodule occupancy (Robleto et al. 1997, 1998). Several rhizobial strains of the genus Bradyrhizobium possess a hydrogen uptake (Hup) system able to recycle the hydrogen evolved by nitrogenase, resulting in more energy efficient nitrogen fixation. The Hup gene cluster has been introduced into various Rhizobium strains (Báscones et al. 2000), and in some strains, high levels of hydrogenase activity were achieved, leading to nodules that release no hydrogen. In a field experiment, the yield of $P$. vulgaris inoculated with a trifolitoxin-producing $\operatorname{Hup}^{+} R$. leguminosarum strain was significantly increased (Iniguez et al. 2004).

S. meliloti possesses several betaine transporters. Bacteroids overexpressing a high-affinity betaine transporter accumulated high concentrations of proline betaine, the endogenous betaine synthesized by alfalfa plants, in nodulated alfalfa plants subjected to salt stress. Moreover, nitrogen fixation was better maintained in nodulated plants (Boscari et al. 2006). A novel pathway for IAA synthesis was introduced into $R$. leguminosarum using a construct containing the iaaM gene from Pseudomonas syringae and 
Table 1 Genetic engineering of rhizobia to obtain abiotic stress tolerance and enhanced nitrogen fixation

\begin{tabular}{|c|c|c|c|c|c|}
\hline Gene & Origin & Host Rhizobium & Enhanced trait or effect & Proposed mechanism & Reference \\
\hline Chimeric nodD & $\begin{array}{l}\text { S. meliloti and } R \text {. } \\
\text { trifolii }\end{array}$ & $\begin{array}{l}\text { R. trifolii and } R \text {. } \\
\text { leguminosarum }\end{array}$ & $\begin{array}{l}\text { Enhanced nitrogen fixation } \\
\text { in Vicia sativa and } \\
\text { Trifolium repens }\end{array}$ & $\begin{array}{l}\text { Enhanced production of } \\
\text { Nod factors }\end{array}$ & Spaink et al. (1989) \\
\hline Sym plasmid & R. leguminosarum & R. leguminosarum & $\begin{array}{l}\text { Acid tolerance in free- } \\
\text { living rhizobia } \\
\text { Enhanced nitrogen fixation } \\
\text { in Trifolium } \\
\text { subterraneum at low } \mathrm{pH}\end{array}$ & $\begin{array}{l}\text { Enhanced efficiency of } \\
\text { nodulation genes located } \\
\text { in the plasmid }\end{array}$ & Chen et al. (1991) \\
\hline Chromosomal DNA & $\begin{array}{l}\text { Salt tolerant Bacillus } \\
\quad s p \text {. }\end{array}$ & R. leguminosarum & $\begin{array}{l}\text { Salt tolerance in free-living } \\
\text { rhizobia } \\
\text { Plant yield and nitrogen } \\
\text { content of nodulated host } \\
\text { lentil in arid soils }\end{array}$ & $\begin{array}{l}\text { Transfer of genes } \\
\text { determining salt tolerance }\end{array}$ & El-Saidi and Ali (1993) \\
\hline nif $A$ and $d c t A B D$ & S. meliloti & S. meliloti & $\begin{array}{l}\text { Enhanced nitrogen fixation } \\
\text { and biomass yield of } \\
\text { alfalfa nodulated plants in } \\
\text { soils with low nitrogen } \\
\text { and organic matter } \\
\text { content }\end{array}$ & $\begin{array}{l}\text { Enhanced regulation of } \\
\text { nitrogen fixation and } \\
\text { increased dicaboxylic } \\
\text { acid import to bacteroids }\end{array}$ & Bosworth et al. (1994) \\
\hline Trifolitoxin & R. leguminosarum & R. etli & $\begin{array}{l}\text { Enhanced nodule } \\
\text { occupancy in host } \\
\text { Phaseolus vulgaris }\end{array}$ & Antibiotic activity & $\begin{array}{l}\text { Robleto et al. } \\
\quad(1997,1998)\end{array}$ \\
\hline Haemoglobin $V H b$ & Vitreoscilla sp. & R. etli & $\begin{array}{l}\text { Nitrogenase activity and } \\
\text { total nitrogen content in } \\
\text { nodulated bean plants }\end{array}$ & $\begin{array}{l}\text { Stimulated respiratory } \\
\text { efficiency in free-living } \\
\text { rhizobia and bacteroids }\end{array}$ & Ramírez et al. (1999) \\
\hline Terminal oxidase $c b b_{3}$ & $\begin{array}{l}\text { Bradyrhizobium } \\
\text { japonicum }\end{array}$ & R. etli ntrC mutant & $\begin{array}{l}\text { Nitrogen fixation in } \\
\text { nodulated Phaseolus } \\
\text { vulgaris plants }\end{array}$ & $\begin{array}{l}\text { Enhanced ATP supply to } \\
\text { nitrogenase }\end{array}$ & Soberón et al. (1999) \\
\hline $\begin{array}{l}\text { Symbiotic gene region } \\
\text { containing nodDl, } \\
\operatorname{nod} A B C \text { and } n i f N\end{array}$ & S. meliloti & S. meliloti & $\begin{array}{l}\text { Nodulation, nitrogenase } \\
\text { activity, plant nitrogen } \\
\text { content and growth in } \\
\text { alfalfa }\end{array}$ & $\begin{array}{l}\text { Increase in Nod factor } \\
\text { production and in } \\
\text { regulation of nitrogen } \\
\text { fixation }\end{array}$ & Castillo et al. (1999) \\
\hline Glycogen synthase $G \lg A$ & R. tropici & R. tropici & $\begin{array}{c}\text { Symbiotic performance and } \\
\text { dry weight of Phaseolus } \\
\text { vulgaris nodulated plants }\end{array}$ & $\begin{array}{l}\text { Block of glycogen } \\
\text { synthesis and putative } \\
\text { pleiotropic effects }\end{array}$ & Marroquí et al. (2001) \\
\hline $\begin{array}{l}\text { Proline dehydrogenase } \\
\text { putA }\end{array}$ & S. meliloti & S. meliloti & $\begin{array}{l}\text { Advantage over natural } \\
\text { rhizobial populations to } \\
\text { infect and nodulate } \\
\text { alfalfa under drought } \\
\text { stress }\end{array}$ & $\begin{array}{l}\text { Oxidation of proline from } \\
\text { alfalfa root exudates to } \\
\text { glutamate as energy } \\
\text { source for rhizobia }\end{array}$ & $\begin{array}{l}\text { Van Dillewijn } \\
\text { et al. }(2001,2002)\end{array}$ \\
\hline $\begin{array}{l}\text { Trifolitoxin and Hup gene } \\
\text { cluster }\end{array}$ & $\begin{array}{l}\text { R. leguminosarum and } \\
\text { Bradyrhizobium sp. }\end{array}$ & R. leguminosarum & $\begin{array}{l}\text { Dry seed weight yield in } \\
\text { nodulated Phaseolus } \\
\text { vulgaris plants }\end{array}$ & $\begin{array}{l}\text { Antibiotic activity and } \\
\text { recycling and oxidation } \\
\text { of hydrogen derived from } \\
\text { nitrogenase activity }\end{array}$ & Iniguez et al. (2004) \\
\hline Betaine transporter BetS & S. meliloti & S. meliloti & $\begin{array}{l}\text { Nitrogen fixation in } \\
\text { nodulated alfalfa } \\
\text { subjected to salt stress }\end{array}$ & $\begin{array}{l}\text { Accumulation of osmolytes } \\
\text { proline betaine and } \\
\text { glycine betaine in } \\
\text { bacteroids under osmotic } \\
\text { stress }\end{array}$ & Boscari et al. (2006) \\
\hline \multirow[t]{3}{*}{$i a a M$ and $t m s 2$} & \multirow{3}{*}{$\begin{array}{l}\text { Pseudomonas syringae } \\
\text { and Agrobacterium } \\
\text { tumefaciens }\end{array}$} & \multirow[t]{3}{*}{$\begin{array}{l}\text { R. leguminosarum and } \\
\text { S. meliloti }\end{array}$} & $\begin{array}{l}\text { Nitrogen fixation in Vicia } \\
\text { hirsuta nodulated plants }\end{array}$ & Enhanced IAA synthesis & Camerini et al. (2008) \\
\hline & & & $\begin{array}{l}\text { Tolerance to heat, cold, salt } \\
\text { and UV-irradiation } \\
\text { stresses in free-living } \\
\text { rhizobia }\end{array}$ & $\begin{array}{l}\text { General hormone } \\
\text { re-modulation in the } \\
\text { plant }\end{array}$ & Imperlini et al. (2009) \\
\hline & & & $\begin{array}{l}\text { Nitrogen-fixing activity, } \\
\text { stem dry weight and salt } \\
\text { tolerance in } M \text {. } \\
\text { truncatula nodulated } \\
\text { plants. }\end{array}$ & & Bianco and Defez (2009) \\
\hline \multirow[t]{2}{*}{ Flavodoxin } & \multirow[t]{2}{*}{ Anabaena variabilis } & \multirow[t]{2}{*}{ S. meliloti } & $\begin{array}{l}\text { Delayed nodule senescence } \\
\text { in alfalfa nodulated plants }\end{array}$ & $\begin{array}{l}\text { Enhanced ROS } \\
\text { detoxification }\end{array}$ & Redondo et al. (2009) \\
\hline & & & $\begin{array}{l}\text { Nitrogen fixation with } \\
\text { enhanced cadmium } \\
\text { tolerance in alfalfa } \\
\text { nodulated plants. }\end{array}$ & $\begin{array}{l}\text { Changes in antioxidant } \\
\text { metabolism }\end{array}$ & Shvaleva et al. (2010) \\
\hline
\end{tabular}

ROS Reactive oxygen species, IAA indole-3-acetic acid 
the tms 2 gene from Agrobacterium tumefaciens under the control of a stationary phase-induced promoter from Agrobacterium rhizogenes (Camerini et al. 2008). The iaaM gene codes for an indolacetamide hydrolase that converts tryptophan into indolacetamide (IAM), and the tms 2 gene encodes a tryptophan monooxigenase that converts IAM into IAA. Free-living bacteria harboring this construct release 14-fold more IAA into the growth medium than wild-type strains. When vetch (Vicia hirsuta) roots were nodulated with the transformed rhizobia, nodules contained up to 60 -fold more IAA than nodules infected by the wildtype strain. These nodules were heavier in terms of dry weight, with enlarged and more active meristems, significantly augmenting nitrogen fixation (Camerini et al. 2008). Free-living $S$. meliloti transformed with the same construct displayed increased activities for some enzymes in the tricarboxylic acid cycle, enhanced acetyl-CoA, and polybeta-hydroxybutyrate content; they accumulated more endogenous osmolyte trehalose and survived better (Imperlini et al. 2009). The transformed bacteria also better tolerated heat, cold, and salt stress, as well as UVirradiation (Imperlini et al. 2009; Bianco and Defez 2009). M. truncatula plants nodulated by the IAA-overexpressing $S$. meliloti strain showed an induction of nitrogen-fixing activity, increased stem dry weight production (Imperlini et al. 2009), and enhanced salt tolerance (Imperlini et al. 2009; Bianco and Defez 2009). Similarly, these $M$. truncatula plants had a higher proline content, almost unchanged hydrogen peroxide levels, enhanced activities of several antioxidant enzymes, reduced foliar senescence, higher nitrogenase activity, and lower expression of ethylene signaling genes than plants nodulated by the wild-type strain. These effects seem to be due to general phytohormone re-modulation in the plant (Bianco and Defez 2009).

Flavodoxins are electron carrier flavoproteins present in prokaryotes and some eukaryotic algae (Erdner et al. 1999). They contain a flavin mononucleotide (FMN) group acting as a redox center that transfers electrons at low potentials (Pueyo et al. 1991; Pueyo and Gómez-Moreno 1991). In cyanobacteria and enterobacteria, flavodoxin levels increase several-fold upon exposure to oxidative stress (Zheng et al. 1999; Yousef et al. 2003). Transformation of S. meliloti with the A. variabilis flavodoxin gene provided enhanced tolerance to stresses involving ROS generation in freeliving bacteria. Flavodoxin-overexpressing $S$. meliloti was used to nodulate alfalfa plants and bacteroids overexpressing flavodoxin induced changes in antioxidant metabolism, affecting antioxidant enzymes, ascorbate-glutathione cycle enzymes and their metabolites, and inducing delayed senescence and starch accumulation in alfalfa root nodules (Redondo et al. 2009). Moreover, the nitrogen-fixing activity of alfalfa nodules elicited by the flavodoxin- overexpressing $S$. meliloti had enhanced tolerance to cadmium stress (Shvaleva et al. 2010). These results suggest that rhizobia overexpressing flavodoxin may serve as biotechnological tools to improve the symbiotic performance of legumes subjected to environmental stress involving damage by ROS generation.

\section{Legume plants for the reclamation of marginal soils}

There are numerous recent studies aimed at identifying legume species with the potential to enhance the cultivation and revegetation of marginal areas. These will be considered along with the current efforts to select stress-tolerant legume varieties by classical methods or transgenic approaches.

\subsection{Selection of new legumes and the breeding of old traits}

Genetic variability within a plant species causes variations in plant responses to abiotic stress and nutrient imbalances, and it allows crops to be selected that are tolerant to abiotic stresses. For example, legumes that grow in saline soils are considered to be naturally selected salt-tolerant genotypes with potential value as genetic resources for saline areas. In fact, the best strategy is to select a tolerant legume in combination with a tolerant Rhizobium (Zahran 1991 and references therein; Herridge and Danso 1995; Howieson and Ballard 2004). However, to a large extent, breeding to improve nitrogen fixation has not been fully successful, maybe due to the difficulty in combining different traits and agricultural management techniques and the lack of screening technologies (Herridge et al. 2001).

Different studies have been performed to identify and select tolerant legume genotypes that can be employed in sustainable agriculture. For example, several studies aimed at identifying salt-tolerant genotypes and to evaluate genotype variation in response to salinity have been carried out in different species and lines of legumes, such as chickpea, Lotus sp. or Trifolium sp. (Rogers et al. 1997; Sadiki and Rabih 2001; Nichols et al. 2008; Teakle et al. 2010). Different drought-tolerant and sensitive cultivars of the important oilseed crop legume, groundnut (Arachis hypogea), have been analyzed to elucidate drought tolerance traits that might enable appropriate genetic enhancement strategies to be developed to increase yield in drought environments (Reddy et al. 2003). The yield of the lentil (Lens culinaris Medik.), a food legume crop, is markedly affected by drought, heat, and salt stress, as well as by iron deficiency. Comparative genomics and a consensus genetic map for the lentil are under development to identify and select resistant germplasm (Muehlbauer et al. 2006 and references therein). Different lines of annual and perennial 
legumes have been tested to evaluate their agronomic potential in semi-arid climates (Small 2003; Caravaca et al. 2003; Merou and Papanastasis 2009). Different legume cultivars have also been tested for drought (Acuna et al. 2010; Kostopoulou et al. 2010), frost (Ratinam et al. 1994; Meyer and Badaruddin 2001), flooding (Vignolio et al. 1999), cold (Gan et al. 2009) and acid (Howieson et al. 1995) tolerance, as well as for winter survival (Annicchiarico and Iannucci 2007). Different perennial legumes that can use phosphorus efficiently were screened for their potential use in revegetating Australian soils with phosphorus deficiency (Pang et al. 2010). The influence of the legume cultivar to improve performance in rotation systems is also being evaluated (Cock 1992; Adjei-Nsiah et al. 2007; Soon and Lupwayi 2008).

There is great interest in rapidly improving both plant and microbial germplasms (Sprent et al. 2010). In Mediterranean areas, shrub legumes and their corresponding rhizobia microsymbionts have a strong potential to enhance nitrogen and carbon levels in arid and acidic soils, making them suitable candidates for revegetation of these areas (Alegre et al. 2004; Rodríguez-Echevarría and PérezFernández 2005; Villar-Salvador et al. 2008). This potential has even been observed in soils containing composted sewage sludge (de Andrés et al. 2007). A new species of the annual arrowleaf clover (Trifolium vesiculosum Savi) has been identified and characterized recently with improved pastoral production in dryland areas in the central-southern region of Chile (Ovalle et al. 2010). Numerous legume tree species have also been tested for their capacity to help revegetate degraded soils in Brazil and Australia (Franco and De Faria 1997). Lupinus argenteus (Pursh.), a legume native to sagebrush steppes, is also of interest for revegetation as it favors nitrogen availability and cycling under conditions of water stress (Goergen et al. 2009). In India, little known wild legumes are being characterized as potential germplasms for use in the reclamation of marginal soils. One example is the biochemical characterization of some Canavalia spp., which are naturally distributed in sand dunes and mangrove areas. The stress-tolerant rhizobia of these plants are also being characterized (Seena and Sridhar 2006). Tropical Stylosanthes species from Australia, Colombia, Brazil, and Ethiopia have been introduced in India, and they constitute a new germplasm to improve soil fertility and provide nutritive forage in rain-fed situations of heavy clay and cracking soil types (Chandra 2009). Different halophytes, including several legumes, were described within the desert flora of Central Asia, and they are very attractive to reclaim degraded and drought-affected soils (Toderich et al. 2009).

Africa has a vast array of indigenous legumes that are adapted to soil and climatic conditions, in particular drought and low nutrients, ranging from large rainforest trees to small annual herbs. These legumes and their rhizobial microsymbionts have so far been a poorly exploited source of germplasms for the revegetation of marginal soils (Sprent et al. 2010). There is a wide diversity of food legumes adapted to drought-prone, low nutrient environments, and they are used in rotation or as intercrops with cereals in Bostwana. Moreover, African tree and shrub legumes are a major source of phytopharmaceuticals (PuleMeuelenberg and Dakora 2007). Malawian smallholder farmers have adopted legumes, mainly edible legume intercrops like pigeon pea and groundnut, to improve both human nutrition and soil fertility (Kerr et al. 2007).

Classical heritability studies of selected traits are also ongoing (Pimratch et al. 2009) and new molecular techniques, such as microsatellite characterization (Lazrek et al. 2009) and transcriptome and proteome studies, will help to better classify and characterize tolerant and sensitive legume cultivars.

\subsection{Transgenic legumes with enhanced stress tolerance}

Several biotechnological approaches are available to enhance biotic and abiotic stress tolerance in legumes, including molecular marker-assisted (MAS) breeding, tissue culture, and gene transformation (Dita et al. 2006 and references therein). Here, we will focus on research developed to obtain abiotic stress-tolerant legumes by gene transformation and expression. A gene transfer method used in legumes involves the use of A. tumefaciens as a vector for transformation (Fig. 3), although $A$. rhizogenes is also used to transform some species to produce composite plants with hairy roots or hairy root cultures. Another method used involves transformation by particle gun bombardment (Eapen 2008 and references therein). The distinct protocols for genetic transformation of the main legumes are in constant development to ensure food and environmental safety (Popelka et al. 2004 and references therein; Eapen 2008 and references therein).

Biotic stresses often involve monogenic traits and several legume cultivars have been transformed in order to enhance resistance to biotic stress (Dita et al. 2006 and references therein). Abiotic stresses generally involve perturbation of several cellular activities and the activation of complex metabolic pathways, as explained above. Tolerance to different abiotic stresses is considered polygenic traits, and therefore, successful genetic transformation to enhance tolerance in legumes requires a thorough physiological and molecular understanding of these stresses. Recent advances in understanding the physiological and molecular events and the pathways involved in abiotic stress and tolerance in legumes, together with progress in developing gene transfer protocols, have helped to generate transgenic legumes with enhanced tolerance to abiotic stresses (Table 2). 
Fig. 3 Agrobacterium-mediated transformation of Medicago truncatula

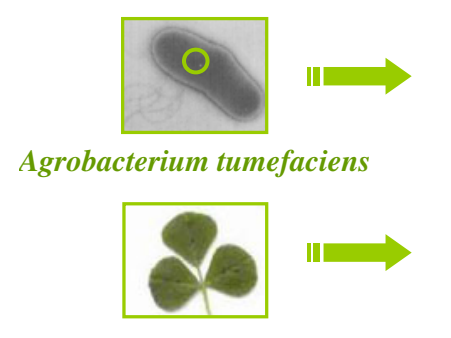

Wild-type M. truncatula

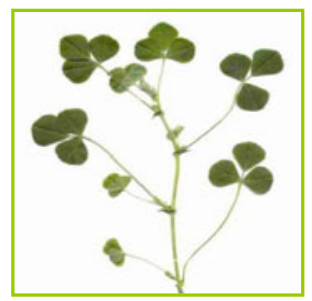

Transgenic M. truncatula

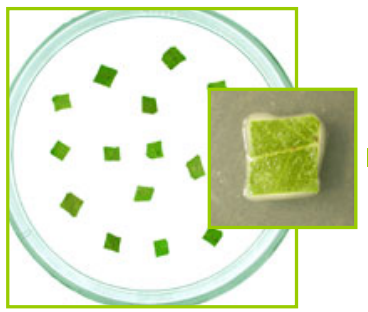

Cocultivation

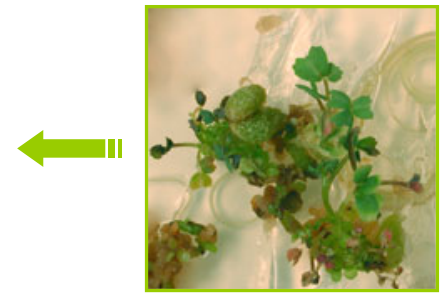

Plantlet regeneration

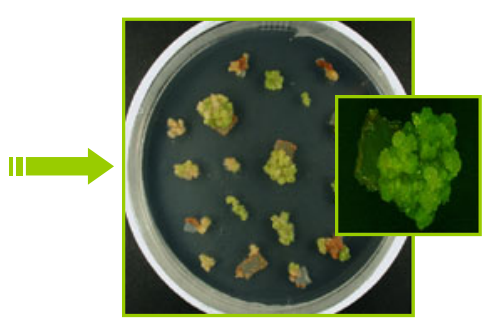

Callus induction

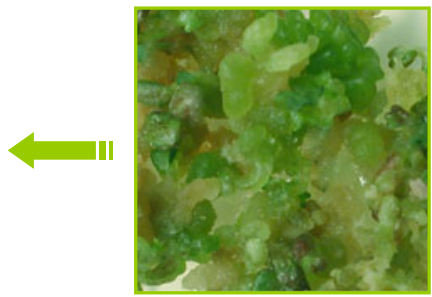

Somatic embryogenesis
Overexpression of the $W X P 1$, a putative M. truncatula AP2 domain-containing transcription factor gene, increases cuticular wax production and accumulation, and it enhances drought tolerance in transgenic alfalfa (Zhang et al. 2005). Indeed, transgenic white clover (T. repens) overexpressing the same WXP1 gene displays improved tolerance to drought stress (Jiang et al. 2010). Alfalfa has been transformed with the AVP1 gene, a vacuolar $\mathrm{H}^{+}$-pyrophosphatase $\left(\mathrm{H}^{+}\right.$-PPase) from Arabidopsis thaliana (Bao et al. 2009). These transgenic plants accumulate more $\mathrm{Na}^{+}, \mathrm{K}^{+}$,

Table 2 Transgenic approaches to engineer abiotic stress tolerance and enhanced nitrogen fixation in legumes

\begin{tabular}{|c|c|c|c|c|c|}
\hline Gene & Origin & $\begin{array}{l}\text { Host } \\
\text { legume }\end{array}$ & $\begin{array}{l}\text { Enhanced trait or } \\
\text { effect }\end{array}$ & Proposed mechanism & Reference \\
\hline Superoxide dismutase & Nicotiana tabacum & $\begin{array}{l}\text { Medicago } \\
\text { sativa }\end{array}$ & $\begin{array}{l}\text { Drought and freezing } \\
\text { stress tolerance, and } \\
\text { winter survival }\end{array}$ & $\begin{array}{l}\text { Enhanced overall defense } \\
\text { system induced by SOD- } \\
\text { induced production of } \mathrm{H}_{2} \mathrm{O}_{2} \text {. } \\
\text { Reduction in secondary ROS } \\
\text { injury symptoms }\end{array}$ & $\begin{array}{l}\text { McKersie et al. (1993, } \\
\text { 1996, 1999, 2000) }\end{array}$ \\
\hline $\begin{array}{l}\text { Putative transcription } \\
\text { factor Alfin } 1\end{array}$ & M. sativa & M. sativa & Salt tolerance & $\begin{array}{l}\text { Enhanced expression of proline- } \\
\text { rich protein } M S P R P 2 \text { and } \\
\text { probably regulation of the } \\
\text { expression of other genes }\end{array}$ & $\begin{array}{l}\text { Winicov and Bastola } \\
\text { (1999) }\end{array}$ \\
\hline Superoxide dismutase & $\begin{array}{l}\text { Nicotiana plumbaginifolia } \\
\text { and Arabidopsis thaliana }\end{array}$ & M. sativa & $\begin{array}{l}\text { Mild water stress } \\
\text { tolerance }\end{array}$ & Enhanced ROS detoxification & Rubio et al. (2002) \\
\hline $\begin{array}{l}\text { Transcription factor } \\
\quad W P X 1\end{array}$ & M. truncatula & M. sativa & Drought tolerance & $\begin{array}{l}\text { Increased cuticular wax } \\
\text { accumulation in leaves }\end{array}$ & Zhang et al. (2005) \\
\hline $\begin{array}{l}\Delta^{1} \text {-pyrroline- } 5 \text { - } \\
\text { carboxylate synthetase } \\
\text { P5CS }\end{array}$ & Vigna aconitifolia & M. truncatula & $\begin{array}{l}\text { Nitrogen fixation under } \\
\text { osmotic stress }\end{array}$ & Proline accumulation & Verdoy et al. (2006) \\
\hline $\begin{array}{l}\text { Antisense beta-1, } \\
\text { 3-glucanase gene } \\
\text { LjGlu1 }\end{array}$ & Lotus japonicus & L. japonicus & $\begin{array}{l}\text { Nodule number and } \\
\text { nitrogen fixation }\end{array}$ & $\begin{array}{l}\text { Unknown mechanism } \\
\text { mediated by } \\
\text { suppressing } L j G l u 1 \\
\text { expression }\end{array}$ & Suzuki et al. (2008) \\
\hline $\begin{array}{l}\text { Vacuolar } \mathrm{H}^{+} \\
\text {-pyrophosphatase } \\
\text { AVP1 }\end{array}$ & A. thaliana & M. sativa & $\begin{array}{l}\text { Salt and drought } \\
\text { tolerance }\end{array}$ & $\begin{array}{l}\text { Enhanced electrochemical } \\
\text { gradient of } \mathrm{H}^{+} \text {across the } \\
\text { tonoplast, favouring } \mathrm{Na}^{+} \\
\text {compartmentalization and } \\
\text { rhizosphere acidification }\end{array}$ & Bao et al. (2009) \\
\hline $\begin{array}{l}\text { Phytase } M t P H Y 1 \text { and } \\
\text { purple acid phosphatase } \\
M t P A P 1\end{array}$ & M. truncatula & $\begin{array}{l}\text { Trifolium } \\
\text { repens }\end{array}$ & $\begin{array}{l}\text { Tolerance to } \\
\text { phosphate } \\
\text { deficiency }\end{array}$ & $\begin{array}{l}\text { Accumulation of total } \\
\text { phosphorus }\end{array}$ & Ma et al. (2009) \\
\hline $\begin{array}{l}\text { Transcription factor } \\
\qquad W P X 1\end{array}$ & M. truncatula & T. repens & Drought tolerance & $\begin{array}{l}\text { Unknown. Putative activation } \\
\text { or suppression of target genes }\end{array}$ & Jiang et al. (2010) \\
\hline Flavodoxin & Anabaena variabilis & M. truncatula & $\begin{array}{l}\text { Nitrogen fixation } \\
\text { under salt stress }\end{array}$ & $\begin{array}{l}\text { Enhanced ROS } \\
\text { detoxification } \\
\text { Changes in antioxidant } \\
\text { metabolism }\end{array}$ & $\begin{array}{l}\text { Coba de la Peña } \\
\text { et al. (2010) }\end{array}$ \\
\hline
\end{tabular}


and $\mathrm{Ca}^{2+}$ in leaves and roots under salt and drought stress conditions, and they retain more water during drought stress. Thus, transgenic plants overexpressing AVP 1 display enhanced tolerance to salt and drought stress. Increased $\mathrm{K}^{+}$ uptake and root activity in transgenic alfalfa may be a consequence of rhizosphere acidification resulting from expression of AVP1. Transgenic expression of Alfin1, a transcription factor that binds to promoter elements in genes regulated by salt or drought stress, improves tolerance to salinity in transgenic alfalfa plants (Winicov and Bastola 1999).

Phosphate is one of the most limiting macronutrients, restricting crop production in many ecosystems. Phytases are enzymes that catalyze the hydrolysis of phytic acid, and a product of this hydrolysis is inorganic phosphate. Purple acid phosphatases are enzymes that hydrolyze phosphate esters and anhydrides under acidic conditions. A phytase gene and a purple acid phosphatase gene, both isolated from the model legume M. truncatula, have been introduced into white clover. Transgenic expression of both these genes in white clover enhanced phytase and acid phosphatase activities in root apoplasts, and transgenic plants were more capable of utilizing organic phosphorus in response to phosphorus deficiency (Ma et al. 2009). It was hypothesized that root nodule formation would be promoted by weaker expression of a beta-1,3-glucanase gene, since expression of this gene is increased in transgenic $L$. japonicus which has reduced nodulation (Suzuki et al. 2008). When the expression of this gene was suppressed by introducing an antisense gene into L. japonicus, transgenic plants harbored more root nodules after inoculation with Mesorhizobium loti, and the nitrogen fixation of transgenic plants was enhanced.

As explained above, plants accumulate proline and other osmolytes under osmotic stress. Transgenic plants that accumulate high levels of proline better tolerate salt and osmotic stress, as well as cold and frost (Kishor et al. 2005 and references therein). Transgenic M. truncatula plants overexpressing the $\Delta^{1}$-pyrroline-5-carboxylate-synthetase (P5CS) gene from Vigna aconitifolia, an enzyme involved in the first two steps of proline biosynthesis, accumulate more proline, resulting in stronger tolerance to salt and osmotic stress when compared with control plants (Verdoy et al. 2006). Transgenic M. truncatula accumulate more proline in leaves, roots and nodules, and the proline levels increase in transgenic plants following salt treatment. When compared to wild-type plants, when subjected to salt stress, the transgenic plants have significantly higher nitrogen-fixing activity and no significant ultrastructural alterations to nodules (Verdoy et al. 2006). To our knowledge, these are the first transgenic legumes that displayed nitrogen-fixing activity with enhanced tolerance to osmotic stress.
A correlation has been suggested between antioxidant levels and tolerance to several abiotic stresses. Transformed plants overexpressing antioxidant enzymes often show increased tolerance to salt and other abiotic stresses, such as drought, cold and heavy metal stress (Ashraf 2009 and references therein). Transgenic alfalfa plants overexpressing a superoxide dismutase (SOD) displayed enhanced tolerance to water deficit, freezing stress and winter survival (McKersie et al. 1993, 1996, 1999, 2000; Rubio et al. 2002). As explained above, flavodoxin expression in $S$. meliloti led to oxidative stress tolerance in alfalfa nodules. Indeed, transgenic tobacco plants expressing a cyanobacterial flavodoxin displayed increased tolerance to multiple sources of stress (Tognetti et al. 2006, 2007a, b). These effects seem to be due to the capacity of flavodoxin to mediate electron transfer and to react with ROS, facilitating ROS detoxification and protecting against oxidative damage. Expression of flavodoxin in transgenic M. truncatula plants does not confer saline tolerance to the whole plant, although the sensitive nitrogen-fixing activity was maintained under salt stress in this transgenic legume (Coba de la Peña et al. 2010). Small but significant flavodoxininduced changes in enzymatic activity associated with the nodule redox balance might be responsible for the positive effect on nitrogen fixation.

\section{Conclusions and prospects}

The studies reviewed here have provided clear evidence of the considerable effort being made to select legume varieties and rhizobial inocula that can fix nitrogen and generate competitive crop yields in degraded and marginal stress-affected soils. Furthermore, better understanding the physiological and molecular mechanisms involved in the tolerance to environmental stresses is giving rise to numerous biotechnological approaches aimed at obtaining improved legumes and rhizobia with enhanced tolerance to abiotic stress, paying particular attention to the sensitive nitrogen-fixing activity.

In a context of global and climate change, with a growing population and an increasing demand for food and feed, the importance of legumes in sustainable agriculture, and particularly in the reclamation of marginal lands, seems beyond any doubt. Needs might diverge in different parts of the globe, often in close connection with the regional development, the natural and acquired richness of the countries and the level of wellbeing, environmental awareness or unacceptable poverty of their peoples. For different and often cumulative reasons, sustainable agriculture is an ever increasing and universal need. While developing countries focus on providing sufficient food to their population, which requires both increasing yields and 
reclaiming yet-unexploited marginal lands, developed states are increasingly aware of the importance of the quality of their food and of the need to restore degraded environments. In either case, improved legumes are equally advantageous. High yields without the added costs of nitrogen fertilization are becoming a must for precarious economies (Chianu et al. 2010, and references therein), whereas chemical-free, organic foods and feed are in increasing demand in advanced societies.

Given that research in the field of legume and inoculant stress tolerance is increasingly necessary, it appears that field experimentation is still insufficient, and laboratory and greenhouse results must be contrasted in cultivation. Despite some astounding success stories, much still remains to be achieved in this respect, which is necessarily associated with technology transfer and the spread of knowledge to farmers, including the acquisition of agricultural management practices to maximize biological nitrogen fixation, such as intercropping or limited tillage. Selecting locally adapted legumes and rhizobia proves to be essential and as such, small scale approaches are indispensable. Regarding transgenic approaches, the perspectives are extremely promising as our understanding of the mechanisms involved in stress tolerance is advancing in great bounds. Transcriptomic approaches are being complemented by proteomics, metabolomics and gene regulation studies, and new genes and traits are being made available to engineer tolerance in the extremely complex legumeRhizobium-soil-climate system. Thus, research is underway, and unprecedented local and global success is expected.

Acknowledgements This work was supported by grants from the Spanish Ministry of Science and Innovation, the Comunidad de Madrid, the Junta de Comunidades de Castilla-La Mancha and the Fundación Ramón Areces.

\section{References}

Acuna H, Inostroza L, Sanchez MP, Tapia G (2010) Drought-tolerant naturalized populations of Lotus tenuis for constrained environments. Acta Agric Scand B Soil Plant Sci 60:174-181. doi:10.1080/09064710902800224

Adjei-Nsiah S, Kuyper TW, Leeuwis C, Abekoe MK, Giller KE (2007) Evaluating sustainable and profitable cropping sequences with cassava and four legume crops: effects on soil fertility and maize yields in the forest/savannah transitional agro-ecological zone of Ghana. Field Crop Res 103:87-97. doi:10.1016/j. fcr.2007.05.001

Ahmad P, Jhon R (2005) Effect of salt stress on growth and biochemical parameters of Pisum sativum L. Arch Agron Soil Sci 51:665-672. doi:10.1080/03650340500274151

Albareda M, Rodríguez-Navarro DN, Temprano FJ (2009) Use of Sinorhizobium (Ensifer) fredii for soybean inoculants in South Spain. Eur J Agron 30:205-211. doi:10.1016/j.eja.2008.10.002
Alegre J, Alonso-Blazquez N, de Andrés EF, Tenorio JL, Eyerbe L (2004) Revegetation and reclamation of soils using wild leguminous shrubs in cold semiarid Mediterranean conditions: litterfall and carbon and nitrogen returns under two aridity regimes. Plant Soil 263:203-212. doi:10.1023/B:PLSO.0000047735.73030.41

Allen ON, Allen EK (1991) The leguminosae: a source book of characteristics, uses and nodulation. University of Wisconsin Press, Madison

Alloing G, Travers I, Sagot B, Le Rudulier D, Dupont L (2006) Proline betaine uptake in Sinorhizobium meliloti: characterization of Prb, an Opp-like ABC transporter regulated by both proline betaine and salinity stress. J Bacteriol 188:6308-6317. doi:10.1128/JB.00585-06

Annicchiarico P, Iannucci A (2007) Winter survival of pea, faba bean and white lupin cultivars in contrasting Italian locations and sowing times, and implications for selection. J Agric Sci 145:611-622. doi:10.1017/S0021859607007289

Aouani ME, Mhamdi R, Mars M, Elayeb M, Ghrir R (1997) Potential for inoculation of common bean by effective rhizobia in Tunisian soils. Agronomie 17:445-454. doi:10.1051/agro:19970902

Arenas-Huertero C, Perez B, Rabanal F, Blanco-Melo D, De la Rosa C, Estrada-Navarrete G, Sánchez F, Covarrubias AA, Reyes JL (2009) Conserved and novel miRNAs in the legume Phaseolus vulgaris in response to stress. Plant Mol Biol 70:385-401. doi:10.1007/s11103-009-9480-3

Arrese-Igor C, González EM, Gordon AJ, Minchin FR, Galvez L, Royuela M, Cabrerizo PM, Aparicio-Tejo PM (1999) Sucrose synthase and nodule nitrogen fixation under drought and other environmental stresses. Symbiosis 27:189-212

Ashraf M (1994) Organic-substances responsible for salt tolerance in Eruca sativa. Biol Plant 36:255-259. doi:10.1007/BF02921095

Ashraf M (2009) Biotechnological approach of improving plant salt tolerance using antioxidants as markers. Biotechnol Adv 27:8493. doi:10.1016/j.biotechadv.2008.09.003

Ashraf M, Waheed A (1993) Responses of some genetically diverse lines of chick pea (Cicer arietinum L.) to salt. Plant Soil 154:257-266. doi:10.1007/BF00012531

Aydi S, Drevon JJ, Abdelly C (2004) Effect of salinity on root-nodule conductance to the oxygen diffusion in the Medicago truncatulaSinorhizobium meliloti symbiosis. Plant Physiol Biochem 42:833-840. doi:10.1016/j.plaphy.2004.10.003

Bano A, Fatima M (2009) Salt tolerance in Zea mays (L). following inoculation with Rhizobium and Pseudomonas. Biol Fertil Soils 45:405-413. doi:10.1007/s00374-008-0344-9

Bao AKB, Wang S-M, Wu G-Q, Xi J-J, Zhang J-L, Wang CM (2009) Overexpression of the Arabidopsis $\mathrm{H}^{+}$-PPase enhanced resistance to salt and drought stress in transgenic alfalfa (Medicago sativa L.). Plant Sci 176:232-240. doi:10.1016/j.plantsci.2008.10.009

Báscones E, Imperial J, Ruiz-Argüeso T, Palacios JM (2000) Generation of new hydrogen-recycling Rhizobiaceae strains by introduction of a novel hup minitransposon. Appl Environ Microbiol 66:4292-4299

Bastiat B, Sauviac L, Bruand C (2010) Dual control of Sinorhizobium meliloti RpoE Sigma factor activity by two PhyR-type twocomponent response regulators. J Bacteriol 192:2255-2265. doi:10.1128/JB.01666-09

Bayuelo-Jimenez JS, Debouck DG, Lynch JP (2003) Growth, gas exchange, water relations, and ion composition of Phaseolus species grown under saline conditions. Field Crop Res 80:207222. doi:10.1016/S0378-4290(02)00179-X

Becana M, Moran JF, Iturbe-Ormaetxe I (1998) Iron-dependent oxygen free radical generation in plants subjected to environmental stress: toxicity and antioxidant protection. Plant Soil 201:137-147. doi:10.1023/A:1004375732137

Becana M, Dalton DA, Moran JF, Iturbe-Ormaetxe I, Matamoros MA, Rubio MC (2000) Reactive oxygen species and antioxidants in 
legume nodules. Physiol Plant 109:372-381. doi:10.1034/j.13993054.2000.100402.x

Ben Rebah F, Prevost D, Yezza A, Tyagi RD (2007) Agro-industrial waste materials and wastewater sludge for rhizobial inoculant production: a review. Bioresour Technol 98:3535-3546. doi:10.1016/j.biortech.2006.11.066

Benedito VA, Torres-Jerez I, Murray JD, Andriankaja A, Allen S, Kakar K, Wandrey M, Verdier J, Zuber H, Ott T, Moreau S, Niebel A, Frickey T, Weiller G, He J, Dai X, Zhao PX, Tang Y, Udvardi MK (2008) A gene expression atlas of the model legume Medicago truncatula. Plant J 55:504-513. doi:10.1111/j.1365313X.2008.03519.x

Bhattacharjee RB, Singh A, Mukhopadhyay SN (2008) Use of nitrogen-fixing bacteria as biofertiliser for non-legumes: prospects and challenges. Appl Microbiol Biotechnol 80:199-209. doi:10.1007/s00253-008-1567-2

Bhattacharya I, Das HR (2003) Cell surface characteristics of two halotolerant strains of Sinorhizobium meliloti. Microbiol Res 158:187-194. doi:10.1078/0944-5013-00195

Bianco C, Defez R (2009) Medicago truncatula improves salt tolerance when nodulated by an indole-3-acetic acidoverproducing Sinorhizobium meliloti strain. J Exp Bot 60:3097-3107. doi:10.1093/jxb/erp140

Binde DR, Menna P, Bangel EV, Barcellos FG, Hungria M (2009) repPCR fingerprinting and taxonomy based on the sequencing of the 16S RNA gene of 54 elite commercial rhizobial strains. Appl Microbiol Biotechnol 83:897-908. doi:10.1007/s00253-0091927-6

Biswas JC, Ladha JK, Dazzo FB (2000a) Rhizobia inoculation improves nutrient uptake and growth of lowland rice. Soil Sci Soc Am J 64:1644-1650

Biswas JC, Ladha JK, Dazzo FB, Yanni YG, Rolfe BG (2000b) Rhizobial inoculation influences seedling vigor and yield of rice. Agron J 92:880-886

Blanco AR, Sicardi M, Frioni L (2010) Competition for nodule occupancy between introduced and native strains of Rhizobium leguminoarum biovar trifolii. Biol Fertil Soils 46:419-425. doi:10.1007/s00374-010-0439-y

Boddey RM, Döbereiner J (1982) Association of Azospirillum and other diazotrophs with tropical gramineae. In: Non symbiotic nitrogen fixation and organic matter in the tropics. Transactions of the 12th International Congress of Soil Science. New Delhi, India, Symposia Papers 1, pp 28-47

Boddey RM, Polidoro JC, Resende AS, Alves BJR, Urquiaga S (2001) Use of the ${ }^{15} \mathrm{~N}$ natural abundance technique for the quantification of the contribution of $\mathrm{N}_{2}$ fixation to sugar cane and other grasses. Aust J Plant Physiol 28:889-895. doi:10.1071/ PP01058

Boddey RM, Urquiaga S, Alves BJR, Reis V (2003) Endophytic nitrogen fixation in sugarcane: present knowledge and future applications. Plant Soil 252:139-149. doi:10.1023/ A: 1024152126541

Bohlool BB, Ladha JK, Garrity DP, George T (1992) Biological nitrogen fixation for sustainable agriculture: a perspective. Plant Soil 141:1-11. doi:10.1007/BF00011307

Boiero L, Perrig D, Masciarelli O, Penna C, Cassan F, Luna V (2007) Phytohormone production by three strains of Bradyrhizobium japonicum and possible physiological and technological implications. Appl Microbiol Biotechnol 74:874-880. doi:10.1007/ s00253-006-0731-9

Boncompagni E, Osteras M, Poggi MC, Le Rudulier D (1999) Occurrence of choline and glycine betaine uptake and metabolism in the family Rhizobiaceae and their roles in osmoprotection. Appl Environ Microbiol 65:2072-2077

Borucki W, Sujkowska M (2008) The effects of sodium chloridesalinity upon growth, nodulation, and root nodule structure of pea
(Pisum sativum L.) plants. Acta Physiol Plant 30:293-301. doi:10.1007/s11738-007-0120-8

Boscari A, Van de Sype G, Le Rudulier D, Mandon K (2006) Overexpression of BetS, a Sinorhizobium meliloti high-affinity betaine transporter, in bacteroids from Medicago sativa nodules sustains nitrogen fixation during early salt stress adaptation. Mol Plant-Microbe Interact 19:896-903. doi:10.1094/MPMI-19-0896

Bosworth AH, Williams MK, Albrecht KA, Kwiatkowski R, Beynon J, Hankinson TR, Ronson CW, Cannon F, Wacek TJ, Triplett EW (1994) Alfalfa yield response to inoculation with recombinant strains of Rhizobium meliloti with an extra copy of $d c t A B D$ and/or modified nifA expression. Appl Environ Microbiol 60:3815-3832

Botsford JL, Lewis TA (1990) Osmoregulation in Rhizobium meliloti: production of glutamic acid in response to osmotic stress. Appl Environ Microbiol 56:488-494

Bouhmouch I, Brhada F, Filali-Maltouf A, Aurag J (2001) Selection of osmotolerant and effective strains of Rhizobiaceae for inoculation of common bean (Phaseolus vulgaris) in Moroccan saline soils. Agronomie 21:591-599. doi:10.1051/agro:2001149

Breedveld MW, Zevenhuizen LPTM, Zehnder AJB (1991) Osmotically induced oligo and polysaccharide synthesis by Rhizobium meliloti SU-47. J Gen Microbiol 136:2511-2519

Breedveld MW, Dijkema C, Zevenhuizen PTM, Zehnder AJB (1993) Response of intracellular carbohydrates to a $\mathrm{NaCl}$ shock in Rhizobium leguminosarum bv. trifolii TA-1 and Rhizobium meliloti SU-47. J Gen Microbiol 139:3157-3163

Brewin NJ (1991) Development of legume root nodules. Annu Rev Cell Biol 7:191-226. doi:10.1146/annurev.cb.07.110191.001203

Brigido C, Alexandre A, Laranjo M, Oliveira S (2007) Moderately acidophilic mesorhizobia isolated from chickpea. Lett Appl Microbiol 44:168-174. doi:10.1111/j.1472-765X.2006.02061.x

Brockwell J, Bottomley PJ (1995) Recent advances in inoculant technology and prospects for the future. Soil Biol Biochem 27:683-697. doi:10.1016/0038-0717(95)98649-9

Brophy LS, Heichel GH (1989) Nitrogen release from roots of alfalfa and soybean grown in sand culture. Plant Soil 116:77-84. doi:10.1007/BF02327259

Busse MD, Bottomley PJ (1989) Growth and nodulation responses of Rhizobium meliloti to water stress induced by permeating and nonpermeating solutes. Appl Environ Microbiol 55:2431-2436

Cabot C, Sibole JV, Barceló J, Poschenrieder C (2009) Abscisic acid decreases leaf $\mathrm{Na}^{+}$exclusion in salt-treated Phaseolus vulgaris $\mathrm{L}$. J Plant Growth Regul 28:187-192. doi:10.1007/s00344-0099088-5

Camerini S, Senatore B, Lonardo E, Imperlini E, Bianco C, Moschetti G, Rotino GL, Campion B, Defez R (2008) Introduction of a novel pathway for IAA biosynthesis to rhizobia alters vetch root nodule development. Arch Microbiol 190:67-77. doi:10.1007/ s00203-008-0365-7

Campbell GR, Sharypova LA, Scheidle H, Jones KM, Niehaus K, Becker A, Walker GC (2003) Striking complexity of lipopolysaccharide defects in a collection of Sinorhizobium meliloti mutants. J Bacteriol 185:3853-3862. doi:10.1128/JB.185.13.3853-3862.2003

Caravaca F, Alguacil MM, Figueroa D, Barea JM, Roldán A (2003) Re-establishment of Retama sphaerocarpa as a target species for reclamation of soil physical and biological properties in a semiarid Mediterranean area. For Ecol Manage 182:49-58. doi:10.1016/S0378-1127(03)00067-7

Castillo M, Flores M, Mavingui P, Martínez-Romero E, Palacios R, Hernández G (1999) Increase in the alfalfa nodulation, nitrogen fixation and plant growth by specific DNA amplification in Sinorhizobium meliloti. Appl Environ Microbiol 65:2716-2722

Chandra A (2009) Diversity among Stylosanthes species: habitat, edaphic and agro-climatic affinities leading to cultivar development. J Environ Biol 30:471-478 
Chang C, Damiani I, Puppo A, Frendo P (2009) Redox changes during the legume-Rhizobium symbiosis. Mol Plant 2:370-377. doi: $10.1093 / \mathrm{mp} / \mathrm{ssn} 090$

Chen TH, Murata N (2002) Enhancement of tolerance of abiotic stress by metabolic engineering of betaines and other compatible solutes. Curr Opin Plant Biol 5:250-257. doi:10.1016/S13695266(02)00255-8

Chen H, Richardson AE, Gartner E, Djordjevic MA, Roughley RJ, Rolfe BG (1991) Construction of an acid-tolerant Rhizobium leguminosarum biovar trifolii strain with enhanced capacity for nitrogen fixation. Appl Environ Microbiol 57:2005-2011

Chen D, Liang MX, DeWald D, Weimer B, Peel MD, Bugbee B, Michaelson J, Davis E, Wu Y (2008) Identification of dehydration responsive genes from two non-nodulated alfalfa cultivars using Medicago truncatula microarrays. Acta Physiol Plant 30:183-199. doi:10.1007/s11738-007-0107-5

Chernyad'ev II (2009) The protective action of cytokinins on the photosynthetic machinery and productivity of plants under stress. Appl Biochem Microbiol 45:351-362. doi:10.1134/ S0003683809040012

Chianu JN, Nkonya EM, Mairura FS, Chianu JN, Akinnifesi FK (2010) Biological nitrogen fixation and socioeconomic factors for legume production in sub-Saharan Africa: a review. Agron Sustain Dev. doi:10.1051/agro/2010004, in press

Clark IM, Mendum TA, Hirsch PR (2002) The influence of the symbiotic plasmid pRL1JI on the distribution of GM rhizobia in soil and crop rhizospheres, and implications for gene flow. Antonie Leeuwenhoek 81:607-616. doi:10.1023/A:1020574009445

Coba de la Peña T, Verdoy D, Redondo FJ, Pueyo JJ (2003) Salt tolerance in the Rhizobium-legume symbiosis: an overview. In: Pandalai SG (ed) Recent research developments in plant molecular biology 1 . Research Signpost, Trivandrum, pp 187-205

Coba de la Peña T, Cárcamo CB, Almonacid L, Zaballos A, Lucas MM, Balomenos D, Pueyo JJ (2008a) A salt stress-responsive cytokinin receptor homologue isolated from Medicago sativa nodules. Planta 227:769-779. doi:10.1007/s00425-007-0655-3

Coba de la Peña T, Cárcamo CB, Almonacid L, Zaballos A, Lucas MM, Balomenos D, Pueyo JJ (2008b) A cytokinin receptor homologue is induced during root nodule organogenesis and senescence in Lupinus albus L. Plant Physiol Biochem 46:219225. doi:10.1016/j.plaphy.2007.10.021

Coba de la Peña T, Cárcamo CB, Lucas MM, Pueyo JJ (2008c) Multiple roles for cytokinin receptors and cross-talk of signalling pathways. Plant Signal Behav 3:791-794

Coba de la Peña T, Redondo FJ, Manrique E, Lucas MM, Pueyo JJ (2010) Nitrogen fixation persists under conditions of salt stress in transgenic Medicago truncatula plants expressing a cyanobacterial flavodoxin. J Plant Biotechnol 8:954-965. doi:10.1111/ j.1467-7652.2010.00519.x

Cock PS (1992) Plant attributes leading to persistence in grazed annual medics (Medicago spp.) growing in rotation with wheat. Aust J Agric Res 43:1559-1570. doi:10.1071/AR9921559

Cooper JE (2007) Early interactions between legumes and rhizobia: disclosing complexity in a molecular dialogue. J Appl Microbiol 103:1355-1365. doi:10.1111/j.1365-2672.2007.03366.x

Cordovilla MP, Ligero F, Lluch C (1999) Effect of salinity on growth, nodulation and nitrogen assimilation in nodules of faba bean (Vicia faba L.). Appl Soil Ecol 11:1-7. doi:10.1016/S0929-1393(98) 00132-2

Dakora FD, Keya SO (1997) Contribution of legume nitrogen fixation to sustainable agriculture in Sub-Saharan Africa. Soil Biol Biochem 29:809-817. doi:10.1016/S0038-0717(96)00225-8

Dalton DA, Russel SA, Hanus FJ, Pascoe GA, Evans HJ (1986) Enzymatic reactions of ascorbate and glutathione that prevent peroxide damage in soybean root nodules. Proc Natl Acad Sci USA 83:3811-3815
Dalton DA, Post CJ, Langeberg L (1991) Effects of ambient oxygen and of fixed nitrogen on concentrations of glutathione, ascorbate, and associated enzymes in soybean root-nodules. Plant Physiol 96:812-818. doi:10.1104/pp.96.3.812

Dalton DA, Langeberg L, Robbins M (1992) Purification and characterization of monodehydroascorbate reductase from soybean root nodules. Arch Biochem Biophys 292:281-286. doi:10.1016/0003-9861(92)90080-G

Dalton DA, Langeberg L, Treneman NC (1993) Correlations between the ascorbate-glutathione pathway and effectiveness in legume root-nodules. Physiol Plant 87:365-370. doi:10.1111/j.13993054.1993.tb01743.x

Danga BO, Ouma JP, Wakindiki IIC, Bar-Tal A (2009) Legume-wheat rotation effects on residual soil moisture, nitrogen and wheat yield in tropical regions. Adv Agronom 101:315-349. doi:10.1016/S0065-2113(08)00805-5

Davies MJ, Puppo A (1992) Direct detection of a globin-derived radical in lehaemoglobin treated with peroxides. Biochem $\mathrm{J}$ 281:197-201

de Andrés F, Walter I, Tenorio JL (2007) Revegetation of abandoned agricultural land amended with biosolids. Sci Total Environ 378:81-83. doi:10.1016/j.scitotenv.2007.01.017

Deaker R, Roughley RJ, Kennedy IR (2004) Legume seed inoculation technology - a review. Soil Biol Biochem 36:1275-1288. doi:10.1016/j.soilbio.2004.04.009

Delauney A, Verma DPS (1993) Proline biosynthesis and osmoregulation in plants. Plant $\mathrm{J}$ 4:215-223. doi:10.1046/j.1365313X.1993.04020215.x

Delgado MJ, Ligero F, Lluch C (1994) Effects of salt stress on growth and nitrogen-fixation by pea, faba-bean, common bean and soybean plants. Soil Biol Biochem 26:371-376. doi:10.1016/ 0038-071(94)90286-0

Ding H, Hynes MF (2009) Plasmid transfer system in the rhizobia. Can J Microbiol 55:917-927. doi:10.1139/W09-056

Dita MA, Rispail N, Prats E, Rubiales D, Singh KB (2006) Biotechnology approaches to overcome biotic and abiotic stress constraints in legumes. Euphytica 147:1-24. doi:10.1007/ s10681-006-6156-9

Djekoun A, Planchon C (1991) Water status effect on dinitrogen fixation and photosynthesis in soybean. Agron J 83:316-322

Dominguez-Ferreras A, Perez-Arnedo R, Becker A, Olivares J, Soto MJ, Sanjuan J (2006) Transcriptome profiling reveals the importance of plasmid pSymB for osmoadaptation of Sinorhizobium meliloti. J Bacteriol 188:7617-7625. doi:10.1128/ JB.00719-06

Duan J, Müller KM, Charles TC, Vesely S, Glick BR (2009) 1aminocyclopropane-1-carboxylate (ACC) deaminase genes in rhizobia from southern Saskatchewan. Microb Ecol 57:423436. doi:10.1007/s00248-008-9407-6

Eapen S (2008) Advances in development of transgenic pulse crops. Biotechnol Adv 26:162-168. doi:10.1016/j.biotechadv.2007.11.001

Egener T, Hurek T, Reinhold-Hurek B (1999) Endophytic expression of nif genes of Azoarcus sp. strain BH72 in rice roots. Mol PlantMicrobe Interact 12:813-819. doi:10.1094/MPMI.1999.12.9.813

El-Akhal MR, Rincón A, Arenal F, Lucas MM, El MN, Barrijal S, Pueyo JJ (2008) Genetic diversity and symbiotic efficiency of rhizobial isolates obtained from nodules of Arachis hypogaea in northwestern Morocco. Soil Biol Biochem 40:2911-2914. doi:10.1016/j.soilbio.2008.08.005

El-Akhal MR, Rincón A, El MN, Pueyo JJ, Barrijal S (2009) Phenotypic and genotypic characterization of rhizobia isolated from root nodules of peanut (Arachis hypogaea L.) grown in Moroccan soils. J Basic Microbiol 49:415-425. doi:10.1002/ jobm.200800359

Elboutahiri N, Thami-alami I, Zaid E, Udupa SM (2009) Genotypic characterization of indigenous Sinorhizobium meliloti and Rhi- 
zobium sullae by rep-PCR, RAPD and ARDRA analyses. Afr J Biotechnol 8:979-985

Elboutahiri N, Thami-Alami I, Udupa SM (2010) Phenotypic and genetic diversity in Sinorhizobium meliloti and S. medicae from drought and salt affected regions of Morocco. BMC Microbiol 10:15. doi:10.1186/1471-2180-10-15

El-Saidi MT, Ali AMM (1993) Towards the rational use of high salinity tolerant plants, vol. 2. In: Leith H, Al-Masoo A (eds). Towards the rational use of high salinity tolerant plants 2. Kluwer Academic, Netherlands, pp 59-65

El-Sheikh EAE, Wood M (1990) Salt effects on survival and multiplication of chickpea and soybean rhizobia. Soil Biol Biochem 22:343-347. doi:10.1016/0038-0717(90)90111C

Erdner DL, Price NM, Doucette GJ, Peleato ML, Anderson DM (1999) Characterization of ferredoxin and flavodoxin as markers of iron limitation in marine phytoplankton. Mar Ecol Prog Ser 184:43-53. doi:10.3354/meps 184043

Essendoubi M, Brhada F, Elijamali JE, Filali-Maltouf A, Bonnassie S, Georgeault S, Blanco C, Jebbar M (2007) Osmoadaptative responses in the rhizobia nodulating Acacia isolated from Southeastern Moroccan Sahara. Environ Microbiol 9:603-611. doi:10.1111/j.1462-2920.2006.01176.x

Evans J (2005) An evaluation of potential Rhizobium inoculant strains used for pulse production in acidic soils of south-east Australia. Aust J Exp Agric 45:257-268. doi:10.1071/EA03129

Evans PJ, Gallesi D, Mathieu C, Hernández MJ, De Felipe M, Halliwell B, Puppo A (1999) Oxidative stress occurs during soybean nodule senescence. Planta 208:73-79. doi:10.1007/ s004250050536

Fedorova E, Redondo FJ, Koshiba T, Pueyo JJ, De Felipe MR, Lucas MM (2005) Aldehyde oxidase (AO) in the root nodules of Lupinus albus and Medicago truncatula: identification of $\mathrm{AO}$ in meristematic and infection zones. Mol Plant-Microbe Interact 18:405-413. doi:10.1094/MPMI-18-0405

Ferguson BJ, Mathesius U (2003) Signaling interactions during nodule development. J Plant Growth Regul 22:47-72. doi:10.1007/s00344-003-0032-9

Fernández-Pascual M, De Lorenzo C, De Felipe MR, Rajalakshmi S, Gordon AJ, Thomas BJ, Minchin FR (1996) Possible reasons for relative salt stress tolerance in nodules of white lupin $\mathrm{cv}$. Multolupa. J Exp Bot 47:1709-1716. doi:10.1093/jxb/ 47.11.1709

Fougère F, Le Rudulier D (1990) Uptake of glycine betaine and its analogues by bacteroids of Rhizobium meliloti. J Gen Microbiol 136:157-163

Fougère F, Le Rudulier D, Streeter JG (1991) Effects of salt stress on amino acid, organic acid, and carbohydrate composition of roots, bacteroids, and cytosol of alfalfa (Medicago sativa L.). Plant Physiol 96:1228-1236. doi:10.1104/pp.96.4.1228

Foyer CH, Graham N (2009) Redox regulation in photosynthetic organisms: signaling, acclimation, and practical implications. Antioxid Redox Signal 11:861-905. doi:10.1089/ars.2008.2177

Franche C, Lindström K, Elmerich C (2009) Nitrogen-fixing bacteria associated with leguminous and non-leguminous plants. Plant Soil 321:35-59. doi:10.1007/s11104-008-9833-8

Franco AA, De Faria SM (1997) The contribution of nitrogen-fixing tree legumes to land reclamation and sustainability in the tropics. Soil Biol Biochem 29:897-903. doi:10.1016/S0038-0717(96)00229-5

Fraysse N, Couderc F, Poinsot V (2003) Surface polysaccharide involvement in establishing the Rhizobium-legume symbiosis. Eur J Biochem 270:1365-1380. doi:10.1046/j.1432-1033.2003.03492.x

Fustec J, Lesuffleur F, Mahieu S, Cliquet J-B (2010) Nitrogen rhizodeposition of legumes. A review. Agron Sustain Dev 30:57-66. doi:10.1051/agro/2009003

Gan Y, Zentner RP, McDonald CL, Warkentin T, Vandenberg A (2009) Adaptability of chickpea in northern high latitude areas- maturity responses. Agric For Meteorol 149:711-720. doi:10.1016/j.agrformet.2008.10.026

Garau G, Yates RJ, Deiana P, Howieson JG (2009) Novel strains of nodulating Burkholderia have a role in nitrogen fixation with papilionoid herbaceous legumes adapted to acid, infertile soils. Soil Biol Biochem 41:125-134. doi:10.1016/j.soilbio.2008.10.011

Garg N, Geetanjali (2007) Symbiotic nitrogen fixation in legume nodules: process and signaling. A review. Agron Sustain Dev 27:59-68. doi:10.1051/agro:2006030

Gemmell LG, Roughley RJ (1993) Field evaluation in acid soils of strains of Rhizobium leguminosarum biovar trifolii selected for their tolerance or sensitivity to acid soil factors in agar medium. Soil Biol Biochem 25:1447-1452. doi:10.1016/0038-0717(93)90060-O

Ghittoni NE, Bueno MA (1995) Peanut rhizobia under salt stress: role of trehalose accumulation in strain ATCC51466. Can J Microbiol 41:1021-1030. doi:10.1139/m95-141

Gholipoor M, Ghasemi-Golezani K, Khooie FR, Moghaddam M (2000) Effects of salinity on initial seedling growth of chickpea (Cicer arietinum L.). Acta Agron Hung 48:337-343. doi:10.1556/AAgr.48.2000.4.3

Giller KE, Wilson K (1991) Nitrogen fixation in tropical cropping systems. CAB International, Wallingford

Glenn AR, Reeve WG, Tiwari RP, Dilworth MJ, Cook GM, Booth IR, Poole RK, Foster JW, Slonczewski JL, Padan E, Epstein W, Skulachev V, Matin A, Fillingame RH (1999) Acid tolerance in root nodule bacteria. In: Chadwick D, Cardew G (eds) Bacterial response to $\mathrm{pH}$. Novartis Foundation Symposium 221, pp 112-130

Glick BR (2005) Modulation of plant ethylene levels by the bacterial enzyme ACC deaminase. FEMS Microbiol Lett 251:1-7. doi:10.1016/j.femsle.2005.07.030

Goergen E, Chambers JC, Blank R (2009) Effects of water and nitrogen availability on nitrogen contribution by the legume, Lupinus argenteus Pursh. Appl Soil Ecol 42:200-208. doi:10.1016/j.apsoil.2009.04.001

Gogorcena Y, Iturbe-Ormaetxe I, Escuredo PR, Becana M (1995) Antioxidant defences against activated oxygen in pea nodules subjected to water stress. Plant Physiol 108:753-759. doi:10.1104/pp.108.2.753

González-Sama A, Lucas MM, de Felipe MR, Pueyo JJ (2004) An unusual infection mechanism and nodule morphogenesis in white lupin (Lupinus albus). New Phytol 163:371-380. doi:10.1111/ j.1469-8137.2004.01121.x

Gordon AJ, Minchin FR, Skot L, James CL (1997) Stress-induced declines in soybean nitrogen fixation are related to nodule sucrose synthase activity. Plant Physiol 114:937-946. doi:10.1104/pp.114.3.937

Gordon LJ, Finlayson CM, Falkenmark M (2010) Managing water in agriculture for food production and other ecosystem services. Agric Water Manage 97:512-519. doi:10.1016/j.agwat.2009.03.017

Gouffi K, Pica N, Pichereau V, Blanco C (1999) Disaccharides as a new class of nonaccumulated osmoprotectants for Sinorhizobium meliloti. Appl Environ Microbiol 65:1491-1500

Govind G, Vokkaliga H, ThammeGowda V, Kalaiarasi PJ, Iyer DR, Muthappa SK, Nese S, Makarla UK (2009) Identification and functional validation of a unique set of drought induced genes preferentially expressed in response to gradual water stress in peanut. Mol Genet Genomics 281:591-605. doi:10.1007/s00438009-0432-z

Graham PH, Vance CP (2000) Nitrogen fixation in perspective: an overview of research and extension needs. Field Crop Res 65:93106. doi:10.1016/S0378-4290(99)00080-5

Graham PH, Vance CP (2003) Legumes: importance and constraints to greater use. Plant Physiol 131:872-877. doi:10.1104/pp.017004

Graham PH, Draeger KJ, Ferrey ML, Conroy MJ, Hammer BE, Martínez E, Aarons SR, Quinto C (1994) Acid pH tolerance in 
strains of Rhizobium and Bradyrhizobium, and initial studies on the basis for acid tolerance of Rhizobium tropici UMR1899. Can J Microbiol 40:198-207. doi:10.1139/m94-033

Guan B, Zhou D, Zhang H, Tian Y, Japhet W, Wang P (2009) Germination responses of Medicago ruthenica seeds to salinity, alkalinity and temperature. J Arid Environ 73:135-138. doi:10.1016/j.jaridenv.2008.08.009

Hellweg C, Puhler A, Weidner S (2009) The time course of the transcriptomic response of Sinorhizobium meliloti 1021 following a shift to acidic pH. BMC Microbiol 9:37. doi:10.1186/14712180-9-37

Hernández-Jiménez MJ, Lucas MM, de Felipe MR (2002) Antioxidant defense and damage in senescing lupin nodules. Plant Physiol Biochem 40:645-657. doi:10.1016/S0981-9428 (02)01422-5

Herridge DF, Danso SKA (1995) Enhancing crop legume nitrogen fixation through selection and breeding. Plant Soil 174:51-82. doi:10.1007/BF00032241

Herridge DF, Turpin JE, Robertson MJ (2001) Improving nitrogen fixation of crop legumes through breeding and agronomic management analysis with simulation modelling. Aust J Exp Agric 41:391-401. doi:10.1071/EA00041

Hinde R, Trautman DA (2002) Symbiosomes. In: Seckbach J (ed) Symbiosis: mechanisms and model systems. Kluwer Academic, Netherlands, pp 207-220

Hirsch PR (1996) Population dynamics of indigenous and genetically modified rhizobia in field. New Phytol 133:159-171. doi:10.1111/j.1469-8137.1996.tb04351.x

Hirsch PR, Spokes JD (1994) Survival and dispersion of geneticallymodified rhizobia in the field and genetic interactions with native strains. FEMS Microbiol Ecol 15:147-159. doi:10.1111/j.15746941.1994.tb00239.x

Hossain MS, Martensson A (2008) Potential use of Rhizobium spp. to improve fitness of non-nitrogen-fixing plants. Acta Agric Scand B Soil Plant Sci 58:352-358. doi:10.1080/09064710701788810

Howieson J, Ballard R (2004) Optimising the legume symbiosis in stressful and competitive environments within southern Australiasome contemporary thoughts. Soil Biol Biochem 36:1261-1273. doi:10.1016/j.soilbio.2004.04.008

Howieson JG, Loi A, Carr SJ (1995) Biserrula pelecinus L.- a legume pasture species with potential for acid, duplex soils which is nodulated by unique root-nodule bacteria. Aust J Agric Res 46:997-1009. doi:10.1071/AR9950997

Hua ST, Tsai VY, Lichens GM, Noma AT (1982) Accumulation of amino acids in Rhizobium sp. strain WR1001 in response to sodium chloride salinity. Appl Environ Microbiol 44:135-140

Hungria M (1995) Efeito das temperaturas elevadas na exsudaçaõ de indutores dos genes nod pelo feijoeiro e soja. In: Hungria M, Balota EL, Colozzi-Filho A, Andrade DS (eds) Microbiologia do Solo: Desafios para o Século XXI. IAPAR/EMBRAPA-CNPSo, Londrina, pp 368-373

Hungria M, Stacey G (1997) Molecular signals exchanged between host plants and rhizobia: basic aspects and potential application in agriculture. Soil Biol Biochem 29:819-830. doi:10.1016/ S0038-0717(96)00239-8

Hungria M, Vargas MAT (2000) Environmental factors affecting nitrogen fixation in grain legumes in the tropics, with an emphasis on Brazil. Field Crops Res 65:151-164. doi:10.1016/ S0378-4290(99)00084-2

Hungria M, Franco AA, Sprent JI (1993) New sources of hightemperature tolerant rhizobia for Phaseolus vulgaris L. Plant Soil 149:103-109. doi:10.1007/BF00010767

Hungria M, Campo RJ, Mendes IC (2003) Benefits of inoculation of the common bean (Phaseolus vulgaris) crop with efficient and competitive Rhizobium tropici strains. Biol Fertil Soils 39:88-93. doi:10.1007/s00374-003-0682-6
Hunt S, Layzell DB (1993) Gas-exchange of legume nodules and the regulation of nitrogenase activity. Annu Rev Plant Physiol Plant Mol Biol 44:483-511. doi:10.1146/annurev.pp.44.060193.002411

Iannetta PPM, James EK, Sprent MI, Minchin FR (1995) Time-course of changes involved in the operation of the oxygen diffusion barrier in white lupin nodules. J Exp Bot 46:565-575. doi: $10.1093 / \mathrm{jxb} / 46.5 .565$

Ikeda J (1994) The effect of short term withdrawal of $\mathrm{NaCl}$ stress on nodulation of white clover. Plant Soil 158:23-27. doi:10.1007/ BF00007913

Imperlini E, Bianco C, Lonardo E, Camerini S, Cermola M, Moschetti G, Defez R (2009) Effects of indole-3-acetic acid on Sinorhizobium meliloti survival and on symbiotic nitrogen fixation and stem dry weight production. Appl Microbiol Biotechnol 83:727738. doi:10.1007/s00253-009-1974-z

Iniguez AL, Robleto EA, Kent AD, Triplett EW (2004) Significant yield increase in Phaseolus vulgaris obtained by inoculation with a trifolitoxin-producing, $\mathrm{Hup}^{+}$strain of Rhizobium leguminosarum bv. phaseoli, Crop Management. Available at http://www. plantmanagementnetwork.org/sub/cm/review/2004/yield/. doi:10.1094/CM-2004-0301-07-RV

Israel DW, Jackson WA (1978) The influence of nitrogen nutrition on ion uptake and translocation by leguminous plants. In: Andrew CS, Kamprath EJ (eds) Mineral nutrition of legumes in tropical and subtropical soils. Commonwealth Scientific and Industrial Research Organization, Melbourne, pp 113129

Iturbe-Ormaetxe I, Escuredo FR, Arrese-Igor C, Becana M (1998) Oxidative damage in pea plants exposed to water deficit or paraquat. Plant Physiol 116:173-181. doi:10.1104/pp.116.1.173

Jain D, Chattopadhyay D (2010) Analysis of gene expression in response to water deficit of chickpea (Cicer arietinum L.) varieties differing in drought tolerance. BMC Plant Biol 10:24. doi:10.1186/1471-2229-10-24

Jensen ES, Hauggaard-Nielsen H (2003) How can increased use of biological nitrogen fixation in agriculture benefit the environment? Plant Soil 252:177-186. doi:10.1023/A:1024189029226

Jeschke WD, Wolf O, Hartung W (1992) Effect of $\mathrm{NaCl}$ salinity on flows and partitioning of $\mathrm{C}, \mathrm{N}$, and mineral ions in whole plants of white lupin (Lupinus albus L.). J Exp Bot 43:777-788. doi:10.1093/jxb/43.6.777

Jiang QZ, Zhang JY, Guo X, Bedair M, Sumner L, Bouton J, Wang ZY (2010) Improvement of drought tolerance in white clover (Trifolium repens) by transgenic expression of a transcription factor gene WPX1. Funct Plant Biol 37:157-165. doi:10.1071/ FP09177

Jin CW, He YF, Tang CX, Wu P, Zheng SJ (2006) Mechanisms of microbially enhanced $\mathrm{Fe}$ acquisition in red clover (Trifolium pratense L.). Plant Cell Environ 29:888-897. doi:10.1111/j.13652005.01468.x

Jones KM, Kobayashi H, Davies BW, Taga ME, Walker GC (2007) How rhizobial symbionts invade plants: the SinorhizobiumMedicago model. Nat Rev Microbiol 5:619-633. doi:10.1038/ nrmicro1705

Jordan DC (1984) Family III Rhizobiaceae CONN 1938, $321^{\text {AL }}$. In: Krieg NR, Holt JG (eds) Bergey's manual of systematic bacteriology. William and Wilkins, Baltimore, pp 235-244

Kakimoto T (2003) Perception and signal transduction of cytokinins. Annu Rev Plant Physiol Plant Mol Biol 54:605-627. doi:10.1146/annurev.arplant.54.031902.134802

Karlen DL, Varvel GE, Bullock DG, Cruse RM (1994) Crop rotations for the 21st century. Adv Agron 53:1-45. doi:10.1016/S00652113(08)60611-2

Keller F, Ludlow MM (1993) Carbohydrate metabolism in droughtstressed leaves of pigeonpea (Cajanus cajan). J Exp Bot 44:1351-1359. doi:10.1093/jxb/44.8.1351 
Kerr RB, Snapp S, Chirwa M, Shumba L, Msachi R (2007) Participatory research on legume diversification with Malawian smallholder farmers for improved human nutrition and soil fertility. Expl Agric 43:437-453. doi:10.1017/S0014479707005339

Kishor PBK, Sangam S, Amrutha RN, Laxmi PS, Naidu KR, Rao KRSS, Rao S, Reddy KJ, Theriappan P, Sreenivasulu N (2005) Regulation of proline biosynthesis, degradation, uptake and transport in higher plants: its implications in plant growth and abiotic stress tolerance. Curr Sci 88:424-438

Kneip C, Lockhart P, Voß C, Maier U-G (2007) Nitrogen fixation in eukaryotes-new models for symbiosis. BMC Evol Biol 7:5566. doi:10.1186/1471-2148-7-55

Kostopoulou P, Vrahnakis MS, Merou T, Lazaridou M (2010) Perennial-like adaptation mechanisms of annual legumes to limited irrigation. J Environ Biol 31:311-314

L'taief B, Sifi B, Zarnan-Allah M, Drevon JJ, Lachaal M (2007) Effect of salinity on root-nodule conductance to the oxygen diffusion in the Cicer arietinum Mesorhizobium ciceri symbiosis. J Plant Physiol 164:1028-1036. doi:10.1016/j.jptph.2006.05.016

Langer H, Nandasena KG, Howieson JG, Jorquera M, Borie F (2008) Genetic diversity of Sinorhizobium meliloti associated with alfalfa in Chilean volcanic soils and their symbiotic effectiveness under acidic conditions. World J Microbiol Biotechnol 24:301308. doi:10.1007/s11274-007-9471-y

Larrainzar E, Wienkoop S, Scherling C, Kempa S, Ladrera R, ArreseIgor C, Weckwerth W, González EM (2009) Carbon metabolism and bacteroid functioning are involved in the regulation of nitrogen fixation in Medicago truncatula under drought and recovery. Mol Plant-Microbe Interact 22:1565-1576. doi:10.1094/MPMI-22-12-1565

Läuchli A (1984) Salt exclusion: an adaptation of legumes for crops and pastures under saline conditions. In: Staples RC, Toenniessen GH (eds) Salinity tolerance in plants-strategies for crop improvement. Wiley, New York, pp 171-188

Lauter DJ, Meiri A, Shuali M (1988) Isoosmotic regulation of cotton and peanut at saline concentrations of $\mathrm{K}$ and $\mathrm{Na}$. Plant Physiol 87:911-916. doi:10.1104/pp.87.4.911

Lazrek F, Roussel V, Ronfort J, Cardinet G, Chardon F, Aouani M, Huguet T (2009) The use of neutral and non-neutral SSRs to analyse the genetic structure of a Tunisian collection of Medicago truncatula lines and to reveal associations with ecoenvironmental variables. Genetica 135:391-402. doi:10.1007/ s10709-008-9285-3

Leslie SB, Israeli B, Lighthart B, Crowe JH, Crowe LM (1995) Trehalose and sucrose protect both membranes and proteins in intact bacteria during drying. Appl Environ Microbiol 61:3592-3597

Leung J, Giraudat J (1998) Abscisic acid signal transduction. Annu Rev Plant Biol 49:199-222. doi:10.1146/annurev.arplant.49.1.199

Li D, Su Z, Dong J, Wang T (2009) An expression database for roots of the model legume Medicago truncatula under salt stress. BMC Genomics 10:517. doi:10.1186/1471-2164-10-517

Lindström K, Jussila MM, Hintsa H, Kaksonen A, Mokelke L, Makelainen K, Pitkajarvi J, Suominen L (2003) Potential of the Galega Rhizobium galegae system for bioremediation of oilcontaminated soil. Food Technol Biotechnol 41:11-16

Liu Y, Wu L, Baddeley JA, Watson CA (2010) Models of biological nitrogen fixation of legumes. A review. Agron Sustain Dev. doi:10.1051/agro/2010008, In Press

Lloret L, Martínez-Romero E (2005) Evolution and phylogeny of rhizobia. Rev Latinoam Microbiol 47:43-60

Lloret J, Bolanos L, Lucas MM, Peart JM, Brewin NJ, Bonilla I, Rivilla R (1995) Ionic stress and osmotic pressure induce different alterations in the lipopolysaccharide of a Rhizobium meliloti strain. Appl Environ Microbiol 61:3701-3704

Lloret J, Wulff BB, Rubio JM, Downie JA, Bonilla I, Rivilla R (1998) Exopolysaccharide II production is regulated by salt in the halotolerant strain Rhizobium meliloti EFB1. Appl Environ Microbiol 64:1024-1028

Loscos J, Matamoros MA, Becana M (2008) Ascorbate and homoglutathione metabolism in common bean nodules under stress conditions and during natural senescence. Plant Physiol 146:1282-1292. doi:10.1104/pp.107.114066

Ma XF, Wright E, Ge YX, Bell J, Xi YJ, Bouton JH, Wang ZY (2009) Improving phosphorus acquisition of white clover (Trifolium repens $\mathrm{L}$.) by transgenic expression of plant-derived phytase and acid phosphatase genes. Plant Sci 176:479-488. doi:10.1016/j. plantsci.2009.01.001

Maj D, Wielbo J, Marek-Kozaczuk M, Martyniuk S, Skorupska A (2009) Pretreatment of clover seeds with Nod factors improves growth and nodulation of Trifolium pratense. J Chem Ecol 35:479-487. doi:10.1007/s10886-009-9672-y

Manchada G, Garg N (2008) Salinity and its effects on the functional biology of legumes. Acta Physiol Plant 30:595-618. doi:10.1007/s11738-008-0173-3

Márquez AJ, Betti M, García-Calderón M, Pal'ove-Balang P, Díaz P, Monza J (2005) Nitrate assimilation in Lotus japonicus. J Exp Bot 56:1741-1749. doi:10.1093/jxb/eri171

Marroquí S, Zorreguieta A, Santamaría C, Temprano F, Soberón M, Megías M, Downie JA (2001) Enhanced symbiotic performance by Rhizobium tropici glycogen synthase mutants. J Bacteriol 183:854-864. doi:10.1128/JB.183.3.854-864.2001

Martínez-Romero E, Segovia E, Mercante FM, Franco AA, Graham PH, Pardo MA (1991) Rhizobium tropicii, a novel species nodulating Phaseolus vulgaris L. beans and Leucaena sp. trees. Int J Syst Bacteriol 41:417-426. doi:10.1099/ 00207713-41-3-417

Masson-Boivin C, Giraud E, Perret X, Batut J (2009) Establishing nitrogen-fixing symbiosis with legumes: how many Rhizobium recipes? Trends Microbiol 17:458-466. doi:10.1016/j. tim.2009.07.004

Matamoros MA, Dalton DA, Ramos J, Clemente MR, Rubio MC, Becana M (2003) Biochemistry and molecular biology of antioxidants in the rhizobia-legume symbiosis. Plant Physiol 133:499-509. doi:10.1104/pp.103.025619

Matamoros MA, Loscos J, Coronado MJ, Ramos J, Sato S, Testillano PS, Tabata S, Becana M (2006) Biosynthesis of ascorbic acid in legume root nodules. Plant Physiol 141:1068-1077. doi:10.1104/ pp. 106.081463

Matos MC, Campos PS, Ramalho JC, Medeira MC, Maia MI, Semedo JM, Marques NM, Matos A (2002) Photosynthetic activity and cellular integrity of the Andean legume Pachyrhizus ahipa (Wedd.) Parodi under heat and water stress. Photosynthetica 40:493-501. doi:10.1023/A:1024331414564

McKersie BD, Chen Y, de Beus M, Bowley SR, Bowler C, Inzé D, D'Halluin K, Botterman J (1993) Superoxide dismutase enhances tolerance of freezing stress in transgenic alfalfa (Medicago sativa L.). Plant Physiol 103:1155-1163. doi:10.1104/pp.103.4.1155

McKersie BD, Bowley SR, Harjanto E, Leprince O (1996) Waterdeficit tolerance and field performance of transgenic alfalfa overexpressing superoxide dismutase. Plant Physiol 111:11771181. doi:10.1104/pp.111.4.1177

McKersie BD, Bowley SR, Jones KS (1999) Winter survival of transgenic alfalfa overexpressing superoxide dismutase. Plant Physiol 119:839-848. doi:10.1104/pp.119.3.839

McKersie BD, Murnaghan J, Jones KS, Bowley SR (2000) Ironsuperoxide dismutase expression in transgenic alfalfa increases winter survival without a detectable increase in photosynthetic oxidative stress tolerance. Plant Physiol 122:1427-1437. doi:10.1104/pp.122.4.1427

McLauchlan K (2006) The nature and longevity of agricultural impacts on soil carbon and nutrients: a review. Ecosystems 9:1364-1382. doi:10.1007/s10021-005-0135-1 
Merchan F, de Lorenzo L, Rizzo SG, Niebel A, Manyani H, Frugier F, Sousa C, Crespi M (2007) Identification of regulatory pathways involved in the reacquisition of root growth after salt stress in Medicago truncatula. Plant J 51:1-17. doi:10.1111/j.1365313X.2007.03117.x

Merou TP, Papanastasis VP (2009) Factors affecting the establishment and growth of annual legumes in semi-arid Mediterranean grasslands. Plant Ecol 201:491-500. doi:10.1007/s11258-008-9550-7

Meyer DW, Badaruddin M (2001) Frost tolerance of ten seedling legume species at four growth stages. Crop Sci 41:1838-1842

Miethling R, Tebbe CC (2004) Resilience of a soil-established, genetically modified Sinorhizobium meliloti inoculant to soil management practices. Appl Soil Ecol 25:161-167. doi:10.1016/ j.apsoil.2003.08.003

Miller KJ, Kennedy EP, Reinhold VN (1986) Osmotic adaptation by gram-negative bacteria: possible role for periplasmic oligosaccharides. Science 231:48-51. doi:10.1126/science.3941890

Miller-Williams M, Loewen PC, Oresnik IJ (2006) Isolation of saltsensitive mutants of Sinorhizobium meliloti strain Rm1021. Microbiology 152:2049-2059. doi:10.1099/mic.0.28937-0

Miransari M, Balakrishnan P, Smith D, Mackenzie AF, Bahrami HA, Malakouti MJ, Rejali F (2006) Overcoming the stressful effect of low $\mathrm{pH}$ on soybean root hair curling using lipochitooligosaccharides. Commun Soil Sci Plant Anal 37:1103-1110. doi:10.1080/ 00103620600586391

Mnasri B, Tajini F, Trabelsi M, Aouani ME, Mhamdi R (2007) Rhizobium gallicum as an efficient symbiont for bean inoculation. Agron Sustain Dev 27:331-336. doi:10.1051/agro:2007024

Moawad H, El-Rahim WMA, El-Aleem DA, Sedera SAA (2005) Persistence of two Rhizobium etli inoculant strains in clay and silty loam soils. J Basic Microbiol 45:438-446. doi:10.1002/ jobm. 200510590

Montero E, Cabot C, Barceló J, Poschenrieder C (1997) Endogenous abscisic acid levels are linked to decreased growth of bush bean plants treated with $\mathrm{NaCl}$. Physiol Plant 101:17-22. doi:10.1111/ j.1399-3054.1997.tb01814.x

Mouhsine B, Prell J, Filali-Maltouf A, Priefer UB, Aurag J (2007) Diversity, phylogeny and distribution of bean rhizobia in saltaffected soils of North-West Morocco. Symbiosis 43:83-96

Muehlbauer FJ, Cho S, Sarker A, McPhee KE, Coyne CJ, Rajesh PN, Ford R (2006) Application of biotechnology in breeding lentil for resistance to biotic and abiotic stress. Euphytica 147:149-165. doi:10.1007/s10681-006-7108-0

Muglia CI, Grasso DH, Aguilar OM (2007) Rhizobium tropici response to acidity involves activation of glutathione synthesis. Microbiol 153:1286-1296. doi:10.1099/mic.0.2006/003483-0

Murphy PJ, Wexler W, Grzemski W, Rao JP, Gordon D (1995) Rhizopines - their role in symbiosis and competition. Soil Biol Biochem 27:525-529. doi:10.1016/0038-0717(95)98627-Z

Murray JD, Karas BJ, Sato S, Tabata S, Amyot L, Szczyglowski K (2007) A cytokinin perception mutant colonized by Rhizobium in the absence of nodule organogenesis. Science 315:101-104. doi:10.1126/science. 1132514

Nandal K, Sehrawat AR, Yadav AS, Vashishat RK, Boora KS (2005) High temperature-induced changes in exopolysaccharides, lipopolysaccharides and protein profile of heat-resistant mutants of Rhizobium sp. (Cajanus). Microbiol Res 160:367-373. doi:10.1016/j.micres.2005.02.011

Nichols PGH, Rogers ME, Craig AD, Albertsen TO, Miller SM, McClements DR, Hughes SJ, D'Antuono MF, Dear BS (2008) Production and persistence of temperate perennial grasses and legumes at five saline sites in southern Australia. Aust J Exp Agric 48:536-552. doi:10.1071/EA07168

Nilsen ET (1992) The influence of water-stress on leaf and stem photosynthesis in Spartium junceum L. Plant Cell Environ 15:455-461. doi:10.1111/j.1365-3040.1992.tb00996.x
Noctor N, Foyer CH (1998) Ascorbate and gluthatione: keeping active oxygen under control. Annu Rev Plant Physiol Plant Mol Biol 49:249-279. doi:10.1146/annurev.arplant.49.1.249

Nogales J, Campos R, BenAbdelkhalek H, Olivares J, Lluch C, Sanjuán J (2002) Rhizobium tropici genes involved in free-living salt tolerance are required for the establishment of efficient nitrogen-fixing symbiosis with Phaseolus vulgaris. Mol PlantMicrobe Interact 15:225-232. doi:10.1094/MPMI.2002.15.3.225

Nunes C, Araújo SS, Silva JM, Fevereiro P, Silva AB (2009) Photosynthesis light curves: a method for screening water deficit resistance in the model legume Medicago truncatula. Ann Appl Biol 155:321-332. doi:10.1111/j.1744-7348.2009.00341.x

Ohashi Y, Saneoka H, Fujita K (2000) Effect of water stress on growth, photosynthesis, and photoassimilate translocation in soybean and tropical pasture legume siratro. Soil Sci Plant Nutr 46:417-425

Oliveira ALM, Urquiaga S, Döbereiner J, Baldani JI (2002) The effect of inoculating endophytic nitrogen-fixing bacteria on micropropagated sugarcane plants. Plant Soil 242:205-215. doi:10.1023/A:1016249704336

Oren A (1999) Bioenergetics aspects of halophilism. Microbiol Mol Biol Rev 63:334-348

Oresnik IJ, Twelker S, Hynes MF (1999) Cloning and characterizaton of a Rhizobium leguminosarum gene encoding a bacteriocin with similarities to RTX toxins. Appl Environ Microbiol 65:2833-2840

Ormeño-Orrillo E (2005) Lipopolysaccharides of rhizobiaceae: structure and biosynthesis. Rev Latinoam Microbiol 47:165-175

Orozco-Mosqueda M, del C, Altimirano-Hernández J, FariasRodríguez R, Valencia-Cantero F, Santoyo G (2009) Homologous recombination and dynamics of rhizobial genomes. Res Microbiol 160:733-741. doi:10.1016/j.resmic.2009.09.011

Ovalle C, del Pozo A, Fernández F, Chavarria J, Arredondo S (2010) Arrowleaf clover (Trifolium vesiculosum Savi): a new species of annual legumes for high rainfall areas of the Mediterranean climate zone of Chile. Chilean J Agric Res 70:170-177. doi:10.4067/S0718-58392010000100018

Pandey RK, Herrera WAT, Villepas AN, Pendelton JW (1984) Drought response of grain legumes under irrigation gradient. III. Plant growth. Agron J 76:557-560

Pang J, Tibbett $M$, Denton MD, Lambers H, Siddique KHM, Bolland MDA, Revell CK, Ryan MH (2010) Variation in seedling growth of 11 perennial legumes in response to phosphorus supply. Plant Soil 328:133-143. doi:10.1007/ s11104-009-0088-9

Parker CA (1986) Legumes and nitrogen fixation; their importance for farming in the future. Impact Sci Soc 36:153-164

Pedersen AL, Feldner HC, Rosendahl L (1996) Effect of proline on nitrogenase activity in symbiosomes from root nodules of soybean (Glycine max L.) subjected to drought stress. J Exp Bot 47:1533-1539. doi:10.1093/jxb/47.10.1533

Peoples MB, Crasswell ET (1992) Biological nitrogen fixation: investments, expectations and actual contributions to agriculture. Plant Soil 141:13-39. doi:10.1007/BF00011308

Pimratch S, Jogloy S, Vorassot N, Toomsan B, Kesmala T, Patanothai A, Holbrook CC (2009) Heritability of nitrogen fixation traits, and phenotypic and genotypic correlations between nitrogen fixation traits with drought resistance traits and yield in peanut. Crop Sci 49:791-800. doi:10.2135/cropsci2008.06.0331

Popelka JC, Terryn N, Higgins TJV (2004) Gene technology for grain legumes: can it contribute to the food challenge in developing countries? Plant Sci 167:195-206. doi:10.1016/j.plantsci.2004.03.027

Priefer UB, Aurag J, Boesten B, Bouhmouch I, Defez R, FilaliMaltouf A, Miklis M, Moawad H, Mouhsine B, Prell J, Schlüter A, Senatore B (2001) Characterisation of Phaseolus symbionts isolated from Mediterranean soils and analysis of genetic factors related to $\mathrm{pH}$ tolerance. J Biotechnol 91:223-236. doi:10.1016/ S0168-1656(01)00329-7 
Priyanka B, Sekhar K, Sunita T, Reddy VD, Rao KV (2010) Characterization of expressed sequence tags (ESTs) of pigeonpea (Cajanus cajan L.) and functional validation of selected genes for abiotic stress tolerance in Arabidopsis thaliana. Mol Genet Genomics 283:273-287. doi:10.1007/s00438-010-0516-9

Pueyo JJ, Gómez-Moreno C (1991) Characterization of the crosslinked complex formed between ferredoxin-NADP ${ }^{+}$reductase and flavodoxin from Anabaena PCC 7119. Biochim Biophys Acta 1059:149-156. doi:10.1016/S0005-2728(05)80199-9

Pueyo JJ, Gómez-Moreno C, Mayhew SG (1991) Oxidation-reduction potentials of ferredoxin $\mathrm{NADP}^{+}$reductase and flavodoxin from Anabaena PCC7119 and of their electrostatic and covalent complexes. Eur J Biochem 202:1065-1071. doi:10.1111/j.14321033.1991.tb16471.x

Pule-Meuelenberg F, Dakora FD (2007) Assessing the biological potential of $\mathrm{N}_{2}$-fixing Leguminosae in Botswana for increased crop yields and commercial exploitation. Afr J Biotechnol 6:325334

Puppo A, Halliwell B (1988) Generation of hydroxyl radicals by soybean nodule leghaemoglobin. Planta 173:405-410. doi:10.1007/BF00401028

Puppo A, Rigaud J, Job D (1981) Role of superoxide anion in leghemoglobin autoxidation. Plant Sci Lett 22:353-360. doi:10.1016/0304-4211(81)90081-X

Puppo A, Groten K, Bastian F, Carzaniga R, Soussi M, Lucas MM, De Felipe MR, Harrison J, Vanacker H, Foyer CH (2005) Legume nodule senescence: roles for redox and hormone signalling in the orchestration of the natural aging process. New Phytol 165:683-701. doi:10.1111/j.1469-8137.2004.01285.x

Rahmani HA, Saleh-rastin N, Khavazi K, Asgharzadeh A, Fewer D, Kiani S, Lindström K (2009) Selection of thermotolerant bradyrhizobial strains for nodulation of soybean (Glycine max L.) in semi-arid regions of Iran. World J Microbiol Biotechnol 25:591-600. doi:10.1007/s11274-008-9927-8

Rai VK (2002) Role of amino acids in plant responses to stresses. Biol Plant 45:481-487. doi:10.1023/A:1022308229759

Ramírez M, Valderrama B, Arredondo-Peter R, Soberón M, Mora J, Hernández G (1999) Rhizobium etli genetically engineered for the heterologous expresion of Vitreoscilla sp. hemoglobin: effects on free-living and symbiosis. Mol Plant-Microbe Interact 12:1008-1015. doi:10.1094/MPMI.1999.12.11.1008

Rao AV, Tak R (2001) Effect of rhizobial inoculation on Albizia lebbeck and its rhizosphere activity in mine spoils. Arid Land Res Manag 15:157-162. doi:10.1080/15324980151062805

Ratinam M, Abdelmoneim AM, Saxena MC (1994) Variations in sugar content and dry matter distribution in roots and their associations with frost tolerance in certain forage legume species. J Agron Crop Sci 173:345-353. doi:10.1111/j.1439-037X.1994.tb00582.x

Raven JA (1986) Biochemical disposal of excess $\mathrm{H}^{+}$in growing plants? New Phytol 104:175-206. doi:10.1111/j.1469-8137.1986. tb00644.x

Reddy TY, Reddu VR, Anbumozhi V (2003) Physiological responses of groundnut (Arachis hypogea L.) to drought stress and its amelioration: a critical review. Plant Growth Regul 41:75-88. doi:10.1023/A:1027353430164

Reddy PCO, Sairanganayakulu G, Thippeswamy M, Reddy PS, Reddy MK, Sudhakar C (2008) Identification of stress-induced genes from the drought tolerant semi-arid legume crop horsegram (Macrotyloma uniflorum (Lam.) Verdc.) through analysis of subtracted expressed sequence tags. Plant Sci 175:372-384. doi:10.1016/j.plantsci.2008.05.012

Redondo FJ, Coba de la Peña T, Morcillo CN, Lucas MM, Pueyo JJ (2009) Overexpression of flavodoxin induces changes in antioxidant metabolism leading to delayed senescence and starch accumulation in alfalfa root nodules. Plant Physiol 149:11661178. doi:10.1104/pp.108.129601
Reis VM, dos Reis FB, Quesada DM, de Oliveira OCA, Alves BJR, Urquiaga S, Boddey RM (2001) Biological nitrogen fixation associated with tropical pasture grasses. Aust J Plant Physiol 28:837-844. doi:10.1071/PP01079

Reitz M, Hoffmann-Hergarten S, Hallmann J, Sikora RA (2001) Induction of sytemic resistance in potato by rhizobacterium Rhizobium etli strain G12 is not associated with accumulation of pathogenesis-related proteins and enhanced lignin biosynthesis. J Plant Dis Prot 108:11-20

Rincón A, Arenal F, González I, Manrique E, Lucas MM, Pueyo JJ (2008) Diversity of rhizobial bacteria isolated from nodules of the gypsophyte Ononis tridentata L. growing in Spanish soils. Microb Ecol 56:223-233. doi:10.1007/s00248-007-9339-6

Robleto EA, Scupham AJ, Triplett EW (1997) Trifolitoxin production in Rhizobium etli strain CE3 increases competitiveness for rhizosphere growth and root nodulation of Phaseolus vulgaris in soil. Mol Plant-Microbe Interact 10:228-233. doi:10.1094/ MPMI.1997.10.2.228

Robleto EA, Kmiecik K, Oplinger ES, Nienhuis J, Triplett EW (1998) Trifolitoxin production increases nodulation competitiveness of Rhizobium etli CE3 under agricultural conditions. Appl Environ Microbiol 64:2630-2633

Rodríguez-Echevarría S, Pérez-Fernández MA (2005) Potencial use of Iberian shrubby legumes and rhizobia inoculation in revegetation projects under acidic soil conditions. Appl Soil Ecol 29:203-208. doi:10.1016/j.apsoil.2004.11.004

Rogers ME, Noble CL, Pederick RJ (1997) Identifying suitable temperature forage legume species for saline areas. Aust J Exp Agric 37:639-645. doi:10.1071/EA96102

Romdhane SB, Aouani ME, Trabelsi M, de Lajudie P, Mhamdi R (2008) Selection of high nitrogen-fixing rhizobia nodulating chickpea (Cicer arietinum) for semi-arid Tunisia. J Agron Crop Sci 194:413-420. doi:10.1111/j.1439-037X.2008.00328.x

Romdhane SB, Trabelsi M, Aouani ME, de Lajudie P, Mhamdi R (2009) The diversity of rhizobia nodulating chickpea (Cicer arietinum) under water deficiency as a source of more efficient inoculants. Soil Biol Biochem 41:2568-2572. doi:10.1016/j. soilbio.2009.09.020

Ross EJ, Kramer SB, Dalton DA (1999) Efectiveness of ascorbate peroxidase in promoting nitrogen fixation in model systems. Phytochemistry 52:1203-1210. doi:10.1016/S0031-9422(99)00407-0

Ruberg S, Tian ZX, Krol E, Linke B, Meyer F, Wang YP, Puhler A, Weidner S, Becker A (2003) Construction and validation of a Sinorhizobium meliloti whole genome DNA microarray: genomewide profiling of osmoadaptative gene expression. J Biotechnol 106:255-268. doi:10.1016/j.jbiotec.2003.08.005

Rubio MC, González EM, Minchin FR, Webb KJ, Arrese-Igor C, Ramos J, Becana M (2002) Effects of water stress on antioxidant enzymes of leaves and nodules of transgenic alfalfa overexpressing superoxide dismutases. Physiol Plant 115:531-540. doi:10.1034/j.1399-3054.2002.1150407.x

Ruiz-Díez B, Fajardo S, Puertas-Mejías MA, de Felipe MR, Fernández-Pascual M (2009) Stress tolerance, genetic analysis and symbiotic properties of root-nodulating bacteria isolated from Mediterranean leguminous shrubs in Central Spain. Arch Microbiol 191:35-46. doi:10.1007/s00203-008-0426-y

Sadiki M, Rabih K (2001) Selection of chickpea (Cicer arietinum) for yield and symbiotic nitrogen fixation ability under salt stress. Agronomie 21:659-666. doi:10.1051/agro:2001158

Sanchez DH, Lippold F, Redestig H, Hannah MA, Erban A, Krämer U, Kopka J, Udvardi MK (2008) Integrative functional genomics of salt acclimatization in the model legume Lotus japonicus. Plant J 53:973-987. doi:10.1111/j.1365313X.2007.03381.x

Sauvage D, Hamelin J, Larher F (1983) Glycine betaine and other structurally related compounds improve the salt tolerance of 
Rhizobium meliloti. Plant Sci Lett 31:291-302. doi:10.1016/ 0304-4211(83)90068-8

Sauviac L, Philippe H, Phok K, Bruand C (2007) An extracytoplasmic function sigma factor acts as a general stress response regulator in Sinorhizobium meliloti. J Bacteriol 189:4204-4216. doi:10.1128/JB.00175-07

Schubert S, Serraj R, Pliesbalzer E, Mengel K (1995) Effect of drought stress on growth, sugar concentrations and amino acid accumulation in nitrogen-fixing alfalfa (Medicago sativa). J Plant Physiol 146:541-546

Seena S, Sridhar KR (2006) Nutritional and microbiological features of little known legumes, Canavalia cathartica Thouars and C. maritima Thouars of the southwest coast of India. Curr Sci 90:1638-1650

Serraj R, Fleurat-Lessard P, Jaillard B, Drevon JJ (1995) Structural changes in the inner-cortex cells of soybean root-nodules are induced by short-term exposure to high salt or oxygen concentrations. Plant Cell Environ 18:455-462. doi:10.1111/j.13653040.1995.tb00380.x

Serraj R, Bona S, Purcell LC, Sinclair TR (1997) Nitrogen accumulation and nodule activity of field-grown "Jackson" soybean in response to water deficits. Field Crops Res 52:109 116. doi:10.1016/S0378-4290(96)01068-4

Serraj R, Vadez VV, Denison RF, Sinclair TR (1999) Involvement of ureides in nitrogen fixation inhibition in soybean. Plant Physiol 119:289-296. doi:10.1104/pp.119.1.289

Sessitsch A, Howieson JG, Perret X, Antoun H, Martínez-Romero E (2002) Advances in Rhizobium research. Crit Rev Plant Sci 21:323-378. doi:10.1080/0735-260291044278

Sevilla M, Kennedy C (2000) Genetic analysis of nitrogen fixation and plant-growth stimulating properties of Acetobacter diazotrophicus, an endophyte of sugarcane. In: Triplett EW (ed) Prokaryotic nitrogen fixation: a model system for analysis of a biological process. Horizon Scientific, Norwich, pp 737-760

Sheokand S, Dhandi S, Swaraj K (1995) Studies on nodule functioning and hydrogen-peroxide scavenging enzymes under salt stress in chickpea nodules. Plant Physiol Biochem 33:561-566

Shvaleva A, Coba de la Peña T, Rincón A, Morcillo CN, García de la Torre VS, Lucas MM, Pueyo JJ (2010) Flavodoxin overexpression reduces cadmium-induced damage in alfalfa root nodules. Plant Soil 326:109-121. doi:10.1007/s11104-009-9985-1

Simões-Araújo JL, Rodríguez RL, Gerhardt LBD, Mondego JMC, Alves-Ferreira M, Rumjanek NG, Margis-Pinheiro M (2002) Identification of differentially expressed genes by cDNA-AFLP technique during heat stress in cowpea nodules. FEBS Lett 515:44-50. doi:10.1016/S0014-5793(02)02416-X

Singleton PW, Bohlool BB (1984) Effect of salinity on nodule formation by soybean. Plant Physiol 74:72-76. doi:10.1104/pp.74.1.72

Skorupska A, Janczarek M, Marczak M, Mazur A, Król J (2006) Rhizobial exopolysacharides: genetic control and symbiotic functions. Microb Cell Fact 5:7. doi:10.1186/1475-2859-5-7

Small E (2003) Distribution of perennial Medicago with particular reference to agronomic potential for the semiarid Mediterranean climate. In: Bennett SJ (ed) New perennial legumes for sustainable agriculture. University of Western Australia Press, Perth, pp 57-80

Smith LT, Smith GM (1989) An osmoregulated dipeptide in stressed Rhizobium meliloti. J Bacteriol 171:4714-4717

Soberón M, López O, Morera C, de Lourdes Girard M, Tabche ML, Miranda J (1999) Enhanced nitrogen fixation in a Rhizobium etli ntrC mutant that overproduces the Bradyrhizobium japonicum symbiotic terminal oxidase $c b b_{3}$. Appl Environ Microbiol 65:2015-2019

Soberón-Chavez G, Nájera R, Oliveira H, Segovia L (1986) Genetic rearrangements of a Rhizobium phaseoli symbiotic plasmid. J Bacteriol 167:487-491

Soon YK, Lupwayi NZ (2008) Influence of pea cultivar and inoculation on the nitrogen budget of a pea-wheat rotation in northwestern Canada. Can J Plant Sci 88:1-9. doi:10.4141/ CJPS06055

Soussi M, Ocaña A, Lluch C (1998) Effects of salt stress on growth, photosynthesis and nitrogen fixation in chickpea (Cicer arietinum L.). J Exp Bot 49:1329-1337. doi:10.1093/jexbot/49.325.1329

Soussi M, Santamaría M, Ocaña A, Lluch C (2001) Effects of salinity on protein and lipopolysaccharide pattern in a salt-tolerant strain of Mesorhizobium ciceri. J Appl Microbiol 90:476-481. doi:10.1046/j.1365-2672.2001.01269.x

Spaink HP, Okker RJH, Wijffelman CA, Tak T, Goosen-de-Roo L, Pees E, van Brussel AAN, Lugtenberg BJJ (1989) Symbiotic properties of rhizobia containing a flavonoid-independent hybrid nodD product. J Bacteriol 171:4045-4053

Spiertz JHJ (2010) Nitrogen, sustainable agriculture and food security. A review. Agron Sustain Dev 30:43-55. doi:10.1051/agro:2008064

Sprent JI, Odee DW, Dakora FD (2010) African legumes: a vital but under-utilized resource. J Exp Bot 61:1257-1265. doi:10.1093/ jxb/erp342

Streeter JG (2003) Effect of trehalose on survival of Bradyrhizobium japonicum during desiccation. J Appl Microbiol 95:484-491. doi:10.1046/j.1365-2672.2003.02017.x

Suzuki A, Yamashita K, Ishihara M, Nakahara KI, Abe M, Kucho KI, Uchiumi T, Higashi S, Arima S (2008) Enhanced symbiotic nitrogen fixation by Lotus japonicus containing an antisense beta-1, 3-glucanase gene. Plant Biotechnol 25:357-360

Swaraj K, Bishnoi NR (1999) Effect of salt stress on nodulation and nitrogen fixation in legumes. Indian J Exp Bot 37:843-848

Szabolcs I (1994) Soils and salinisation. In: Pessarakali M (ed) Handbook of plant and crop stress. Marcel Dekker, New York, pp $3-11$

Talibart R, Jebbar M, Gouesbet G, Himdi-Kabbab S, Wroblewski H, Blanco C, Bernard T (1994) Osmoadaptation in rhizobia: ectoine-induced salt tolerance. J Bacteriol 176:5210-5217

Talibart R, Jebbar M, Gouffi K, Pichereau V, Gouesbet G, Blanco C, Bernard T, Pocard J (1997) Transient accumulation of glycine betaine and dynamics of endogenous osmolytes in salt-stressed cultures of Sinorhizobium meliloti. Appl Environ Microbiol 63:4657-4663

Tang R, Li C, Xu K, Du YH, Xia T (2010) Isolation, functional characterization, and expression pattern of a vacuolar $\mathrm{Na}^{+} / \mathrm{H}^{+}$ antiporter gene TrNHX1 from Trifolium repens L. Plant Mol Biol Rep 28:102-111. doi:10.1007/s11105-009-0135-y

Teakle NL, Real D, Colmer TD (2006) Growth and ion relations in response to combined salinity and waterlogging in the perennial forage legume Lotus corniculatus and Lotus tenuis. Plant Soil 289:369-383. doi:10.1007/s11104-006-9146-8

Teakle NL, Snell A, Real D, Barrett-Lennard EG, Colmer TD (2010) Variation in salinity tolerance, early shoot mass and shoot ion concentration within Lotus tenuis: towards a perennial pasture legume for saline land. Crop Pasture Sci 61:379-388. doi: $10.1071 / \mathrm{CP} 09318$

Thrall PH, Millsom DA, Jeavons AC, Waayers M, Harvey GR, Bagnall DJ, Brockwell J (2005) Seed inoculation with effective root-nodule bacteria enhances revegetation success. J Appl Ecol 42:740-751. doi:10.1111/j.1365-2664.2005.01058.x

Thrall PH, Broadhurst LM, Hoque MS, Bagnall DJ (2009) Diversity and salt tolerance of native Acacia rhizobia isolated from saline and non-saline soils. Austral Ecol 34:950-963. doi:10.1111/ j.1442-9993.2009.01998.x

Toderich KN, Shuyskaya EV, Ismail S, Gismatullina LG, Radjabov T, Bekchanov BB, Aralova DB (2009) Phytogenetic resources of halophytes of central Asia and their role for rehabilitation of sandy desert degraded rangelands. Land Degrad Dev 20:386396. doi:10.1002/ldr.936

Tognetti VB, Palatnik JF, Fillat MF, Melzer M, Hajirezael M-R, Valle EM, Carrillo N (2006) Functional replacement of 
ferredoxin by a cyanobacterial flavodoxin in tobacco confers broad-range stress tolerance. Plant Cell 18:2035-2050. doi:10.1105/tpc. 106.042424

Tognetti VB, Monti MR, Valle EM, Carrillo N, Smania A (2007a) Detoxification of 2, 4-dinitrotoluene by transgenic plants expressing a bacterial flavodoxin. Environ Sci Technol 41:4071-4076. doi:10.1021/es070015y

Tognetti VB, Zurbriggen MD, Morandi EN, Fillat MF, Valle EM, Hajirezael M-R, Carrillo N (2007b) Enhanced plant tolerance to iron starvation by functional substitution of chloroplast ferredoxin with a bacterial flavodoxin. Proc Natl Acad Sci USA 104:11495-11500. doi:10.1073/pnas.0704553104

Tran LSPT, Urao T, Qin F, Maruyama K, Kakimoto T, Shinozaki K, Yamaguchi SK (2007) Functional analysis of AHK1/ATHK1 and cytokinin receptor histidine kinases in response to abscisic acid, drought, and salt stress in Arabidopsis. Proc Natl Acad Sci USA 104:20623-20628. doi:10.1073/pnas.0706547105

Trevors JT (1986) Plasmid curing in bacteria. FEMS Microbiol Rev 32:149-157

Triplett EW, Barta TM (1987) Trifolitoxin production and nodulation are necessary for the expression of superior nodulation competitiveness by Rhizobium leguminosarum bv. trifolii strain T24 on clover. Plant Physiol 85:335-342. doi:10.1104/pp.85.2.335

Tu JC (1981) Effect of salinity on Rhizobium-root hair interaction, nodulation and growth of soybean. Can J Plant Sci 61:231-239. doi:10.4141/cjps81-035

Udvardi MK, Day DA (1997) Metabolite transport across symbiotic membranes of legume nodules. Annu Rev Plant Physiol Plant Mol Biol 48:493-523. doi:10.1146/annurev.arplant.48.1.493

Van Dillewijn P, Soto MJ, Villadas PJ, Toro N (2001) Construction and environmental release of a Sinorhizobium meliloti strain genetically modified to be more competitive for alfalfa nodulation. Appl Environ Microbiol 67:3860-3865. doi:10.1128/ AEM.67.9.3860-3865.2001

Van Dillewijn P, Soto MJ, Villadas PJ, Toro N (2002) Effect of a Sinorhizobium meliloti strain with a modified putA gene on the rhizosphere microbial community of alfalfa. Appl Environ Microbiol 67:4201-4208. doi:10.1128/AEM.68.9.4201-4208.2002

Van Heerden PDR, Kiddle G, Pellny TK, Mokwala PW, Jordaan A, Strauss AJ, De Beer M, Schlueter U, Kunert KJ, Foyer CH (2008) Regulation of respiration and the oxygen diffusion barrier in soybean protect symbiotic nitrogen fixation from chillinginduced inhibition and shoots from premature senescence. Plant Physiol 148:316-327. doi:10.1104/pp.108.123422

Vanderlinde EM, Muszynski A, Harrison JJ, Koval SF, Foreman DL, Ceri H, Kannenberg EL, Carlson RW, Yost CK (2009) Rhizobium leguminosarum biovar viciae 3841, deficient en 27 hydroxyoctacosanoate-modified lipopolysaccharide, is impaired in dessication tolerance, biofilm formation and motility. Microbiol SGM 155:3055-3069. doi:10.1099/mic.0.025031-0

Vanderlinde EM, Harrison JJ, Muszynski A, Carlson RW, Turner RJ, Yost CK (2010) Identification of a novel ABC transporter required for desicattion tolerance, and biofilm formation in Rhizobium leguminosarum bv. viciae 3841. FEMS Microbiol Ecol 71:327-340. doi:10.1111/j.1574-6941.2009.00824.x

Vargas AAT, Graham PH (1989) Cultivar and $\mathrm{pH}$ effects on competition for nodules sites between isolates of Rhizobium in beans. Plant Soil 117:195-200. doi:10.1007/BF02220712

Vargas MAT, Hungria M (1997) Fixação biológica do nitrogen na cultura da soja. In: Vargas MAT, Hungria M (eds) Biologia dos Solos de Cerrados. EMBRAPA-CPAC, Planaltina, pp 297-360

Vargas LK, Lisboa BB, Schlindwein G, Granada CE, Giongo A, Beneduzi A, Passaglia LMP (2009) Occurrence of plant growthpromoting traits in clover-nodulating rhizobia strains isolated from different soils in Rio Grande do Sul State. Rev Bras Ciênc Solo 33:1227-1235. doi:10.1590/S0100-06832009000500016
Varshney RK, Hiremath PJ, Lekha P, Kashiwagi J, Balaji J, Deokar AA, Vadez V, Xiao Y, Srinivasan R, Gaur PM, Siddique KHM, Town CD, Hoisington DA (2009) A comprehensive resource of drought- and salinity-responsive ESTs for gene discovery and marker development in chickpea (Cicer arietinum L.). BMC Genomics 10:523. doi:10.1186/1471-2164-10-523

Velthof GL, Oudendag D, Witzke HP, Asman WAH, Klimont Z, Oenema O (2009) Integrated assessment of nitrogen emissions form agriculture in EU-27 using MITERRA EUROPE. J Environ Qual 38:402-417. doi:10.2134/jeq2008.0108

Verdoy D, Lucas MM, Manrique E, Covarrubias AA, De Felipe MR, Pueyo JJ (2004) Differential organ-specific response to salt stress and water deficit in nodulated bean (Phaseolus vulgaris). Plant Cell Environ 27:757-767. doi:10.1111/j.1365-3040.2004.01179.x

Verdoy D, Coba de la Peña T, Redondo FJ, Lucas MM, Pueyo JJ (2006) Transgenic Medicago truncatula plants that accumulate proline display nitrogen-fixing activity with enhanced tolerance to osmotic stress. Plant Cell Environ 29:1913-1923. doi:10.1111/ j.1365-3040.2006.01567.x

Verma SC, Ladha JK, Tripathi AK (2001) Evaluation of plant growth promoting and colonization ability of endophytic diazotrophs from deep water rice. J Biotechnol 91:127-141. doi:10.1016/ S0168-1656(01)00333-9

Vignolio OR, Fernández ON, Maceira NO (1999) Flooding tolerance in five populations of Lotus glaber Mill. (Syn. Lotus tenuis Waldst. et. Kit.). Aust J Agric Res 50:555-559. doi:10.1071/A98112

Villar-Salvador P, Valladares F, Domínguez-Lerena S, Ruíz-Díez B, Fernández-Pascual M, Delgado A, Penuelas JL (2008) Functional traits related to seedling performance in the Mediterranean leguminous shrub Retama sphaerocarpa: insights from a provenance, fertilization, and rhizobial inoculation study. Environ Exp Bot 64:145-154. doi:10.1016/j.envexpbot.2008.04.005

Vriezen JAC, De Bruijn FJ, Nüsslein K (2007) Responses of rhizobia to desiccation in relation to osmotic stress, oxygen and temperature. Appl Environ Microbiol 73:3451-3459. doi:10.1128/AEM.02991-06

Wang ET, Martínez-Romero E (2000) Phylogeny of root- and stemnodule bacteria associated with legumes. In: Triplett EW (ed) Prokaryotic nitrogen fixation: a model system for analysis of a biological process. Horizon Scientific, Wymondham, pp 177-186

Watkin ELJ, O'Hara GW, Glenn AR (2003) Physiological responses to acid stress of an acid-soil tolerant and an acid-soil sensitive strain of Rhizobium leguminosarum biovar trifolii. Soil Biol Biochem 35:621-624. doi:10.1016/S0038-0717(03)00012-9

Wei W, Jiang J, Li X, Wang L, Yang SS (2004) Isolation of saltsensitive mutants from Sinorhizobium meliloti and characterization of genes involved in salt tolerance. Lett Appl Microbiol 39:278-283. doi:10.1111/j.1472-765X.2004.01577.x

Wei GH, Yang XY, Zhang ZX, Yang YZ, Lindström K (2008) Strain Mesorhizobium sp. CCNWGX035: a stress-tolerant isolate from Glycyrrhiza glabra displaying a wide host range for nodulation. Pedosphere 18:102-112. doi:10.1016/S1002-0160(07)60108-8

Weir BS (2009). The current taxonomy of rhizobia. New Zealand rhizobia website. Available at http://www.rhizobia.co.nz/taxonomy/rhizobia. htlm. Partially updated 14th September 2009

Weisskopf L, Akello P, Milleret R, Khan ZR, Schulthess F, Gobat JM, Le Bayon R-C (2009) White lupin leads to increased maize yield through a soil fertility-independent mechanism: a new candidate for fighting Striga hermonthica infestation? Plant Soil 319:101-114. doi:10.1007/s11104-008-9853-4

Winicov I, Bastola DR (1999) Transgenic overexpression of the transcription factor Alfin1 enhances expression of the endogenous $M S P R P 2$ gene in alfalfa and improves salinity tolerance of the plants. Plant Physiol 120:473-480. doi:10.1104/pp.120.2.473

Winter E, Läuchli A (1982) Salt tolerance of Trifolium alexandrinum L.: I. Comparison of the salt response of Trifolium alexandrinum 
and T. pratense. Aust J Plant Physiol 9:221-226. doi:10.1071/ PP9820221

Yajima A, van Brussel AA, Schripsema J, Nukada T, Yabuta G (2008) Synthesis and stereochemistry-activity relationship of small bacteriocin, an autoinducer of the symbiotic nitrogen-fixing bacterium Rhizobium leguminosarum. Org Lett 10:2047-2050. doi:10.1021/o18005198

Yanni YG, Rizk RY, Squartini A, Ninke K, Philip-Hollingsworth S, Orgambide G, de Bruijn F, Stoltzfus J, Buckley D, Schmidt TM, Mateos PF, Ladha JK, Dazzo FB (1997) Natural endophytic association between Rhizobium leguminosarum bv. trifolii and rice roots and assessment of its potential to promote rice growth. Plant Soil 194:99-114. doi:10.1023/A:1004269902246

Yanni YG, Rizk RY, El-Fattah FKA, Squartini A, Corich V, Giacomini A, de Bruijn F, Rademaker J, Maya-Flores J, Ostrom P, VegaHernandez M, Hollingsworth RI, Martínez-Molina E, Mateos P, Velazquez E, Wopereis J, Triplett E, Umali-Garcia M, Anarna JA, Rolfe BG, Ladha JK, Hill J, Mujoo R, Ng PK, Dazzo FB (2001) The beneficial plant-growth promoting association of Rhizobium leguminosarum bv. trifolii with rice roots. Aust J Plant Physiol 28:845-870. doi:10.1071/PP01069

Yousef N, Pistorius EK, Michel KP (2003) Comparative analysis of idiA and isiA transcription under iron starvation and oxidative stress in Synechococcus elongatus PCC 7942 wild-type and selected mutants. Arch Microbiol 180:471-483. doi:10.1007/s00203-003-0618-4

Zahran HH (1991) Conditions for successful Rhizobium-legume symbiosis in saline environments. Biol Fertil Soils 12:73-80. doi:10.1007/BF00369391
Zahran HH (1999) Rhizobium-legume symbiosis and nitrogen fixation under severe conditions and in an arid climate. Microbiol Mol Biol Rev 63:968-989

Zahran HH (2001) Rhizobia from wild legumes: diversity, taxonomy, ecology, nitrogen fixation and biotechnology. J Biotechnol 91:143-153. doi:10.1016/S0168-1656(01)00342-X

Zahran HH, Sprent JI (1986) Effects of sodium chloride and polyethylene glycol on root-hair infection and nodulation of Vicia faba L. plant by Rhizobium leguminosarum. Planta 167:303-309. doi:10.1007/BF00391332

Zdunek-Zastocka E (2008) Molecular cloning, characterization and expression analysis of three aldehyde oxidase genes from Pisum sativum L. Plant Physiol Biochem 46:19-28. doi:10.1016/ plaphy.2007.09.011

Zengeni R, Giller KE (2007) Effectiveness of indigenous soyabean rhizobial isolates to fix nitrogen under field conditions of Zimbabwe. Symbiosis 43:129-135

Zhang JY, Broeckling CD, Blancaflor EB, Sledge MK, Sumner LW, Wang ZY (2005) Overexpression of WXP1, a putative Medicago truncatula AP2 domain-containing transcription factor gene, increases cuticular wax accumulation and enhances drought tolerance in transgenic alfalfa (Medicago sativa). Plant $\mathrm{J}$ 42:689-707. doi:10.1111/j.1365-313X.2005.02405.x

Zheng M, Doan B, Schneider TD, Storz G (1999) OxyR and SoxRS regulation of fur. J Bacteriol 181:4639-4643

Zhu JK (2002) Salt and drought stress signal transduction in plants. Ann Rev Plant Biol 53:247-273. doi:10.1146/annurev. arplant.53.091401.143329 